\title{
Density and Absolute Salinity of the Baltic Sea 2006-2009
}

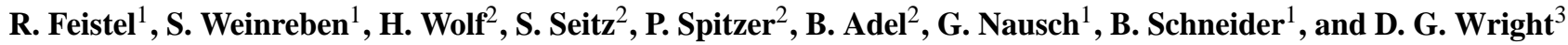 \\ ${ }^{1}$ Leibniz Institute for Baltic Sea Research, 18119 Warnemünde, Germany \\ ${ }^{2}$ Physikalisch-Technische Bundesanstalt, 38116 Braunschweig, Germany \\ ${ }^{3}$ Bedford Institute of Oceanography, Dartmouth, NS, Canada
}

Received: 3 August 2009 - Published in Ocean Sci. Discuss.: 19 August 2009

Revised: 10 December 2009 - Accepted: 17 December 2009 - Published: 18 January 2010

\begin{abstract}
The brackish water of the Baltic Sea is a mixture of ocean water from the Atlantic/North Sea with fresh water from various rivers draining a large area of lowlands and mountain ranges. The evaporation-precipitation balance results in an additional but minor excess of fresh water. The rivers carry different loads of salts washed out of the ground, in particular calcium carbonate, which cause a composition anomaly of the salt dissolved in the Baltic Sea in comparison to Standard Seawater. Directly measured seawater density shows a related anomaly when compared to the density computed from the equation of state as a function of Practical Salinity, temperature and pressure.

Samples collected from different regions of the Baltic Sea during 2006-2009 were analysed for their density anomaly. The results obtained for the river load deviate significantly from similar measurements carried out forty years ago; the reasons for this decadal variability are not yet fully understood. An empirical formula is derived which estimates Absolute from Practical Salinity of Baltic Sea water, to be used in conjunction with the new Thermodynamic Equation of Seawater 2010 (TEOS-10), endorsed by IOC/UNESCO in June 2009 as the substitute for the 1980 International Equation of State, EOS-80. Our routine measurements of the samples were accompanied by studies of additional selected properties which are reported here: conductivity, density, chloride, bromide and sulphate content, total $\mathrm{CO}_{2}$ and alkalinity.
\end{abstract}

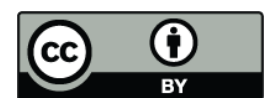

Correspondence to: $\mathrm{R}$. Feistel (rainer.feistel@io-warnemuende.de)

\section{Introduction}

In June 2009, the International Thermodynamic Equation of Seawater 2010 (TEOS-10, IOC, 2010) was endorsed by the $\mathrm{IOC}^{1}$ on its 25th General Assembly in Paris; it will be adopted as a new world-wide standard for oceanography on the 1 January 2010. TEOS-10 takes Absolute Salinity, $S_{\mathrm{A}}$, (the mass fraction of sea salt in seawater) as its input variable to represent the concentration of dissolved sea salt in seawater. This choice contrasts with its predecessor, the International Equation of State of Seawater 1980 (EOS-80) which is formulated in terms of Practical Salinity, $S_{\mathrm{P}}$, measured on the Practical Salinity Scale of 1978 (PSS-78) and representing a measure of the conductivity of a seawater sample. For the first time in the history of oceanographic standards since 1902, this conceptual transition encourages an explicit consideration of composition anomalies in the world ocean (McDougall et al., 2009) as well as in estuaries such as the Baltic Sea. In practice, this choice requires the development of conversion formulae from Practical Salinity, available for example from a CTD cast, to Absolute Salinity involving additional parameters such as estimates of the composition anomalies or the geographic position, the depth and, if the anomalies vary significantly on seasonal or climatological scales, the time.

For the Baltic Sea, such an algorithm was first published by Millero and Kremling (1976), derived from extensive measurements (Kremling, 1969, 1970, 1972). Since later studies revealed relevant systematic changes of the empirical coefficients (Kremling and Wilhelm, 1997), the first and main aim of this paper is to propose an updated empirical formula for the computation of Absolute Salinity of Baltic seawater, based on samples taken between 2006 and 2009, for use in conjunction with TEOS-10, as recommended by the IOC with its recent Resolution XXV-7 (IOC, 2009).

\footnotetext{
${ }^{1}$ IOC: Intergovernmental Oceanographic Commission, http://ioc-unesco.org
}

Published by Copernicus Publications on behalf of the European Geosciences Union. 
The composition anomaly of the salt dissolved in the Baltic Sea compared to the composition of Standard Seawater (Millero et al., 2008) is mainly caused by dissolution of $\mathrm{CaCO}_{3}$ in river water and the subsequent input of $\mathrm{Ca}^{2+}$ and alkalinity/total $\mathrm{CO}_{2}$ into the Baltic Sea by river discharge (Rohde, 1966; Nehring and Rohde, 1967; Kremling, 1969, 1970, 1972; Millero and Kremling, 1976). The alkalinity excess controls the $\mathrm{pH}$ of the Baltic Sea surface water which at the present atmospheric $\mathrm{CO}_{2}$ partial pressure ranges between 7.8 and 8.2 (Nehring, 1980) and is similar to the $\mathrm{pH}$ of ocean water (Millero, 2007; Marion et al., 2009). Below the permanent pycnocline, the $\mathrm{pH}$ may decrease to 7.0-7.3 (Fonselius, 1967) due to the the accumulation of $\mathrm{CO}_{2}$ by the mineralization of organic matter. The second aim of this paper is to estimate the salinity anomaly on the basis of the state of the Baltic Sea $\mathrm{CO}_{2}$ system characterized by the alkalinity and total $\mathrm{CO}_{2}$ concentrations. On climatological time scales the alkalinity in the Baltic Sea may increase because the rising atmospheric $\mathrm{CO}_{2}$ may enhance the weathering of $\mathrm{CaCO}_{3}$ in the catchment area. The increased alkalinity input may affect the salinity anomaly but also has consequences for the Baltic Sea acid/base system since it counteracts the $\mathrm{pH}$ decrease associated with increasing atmospheric $\mathrm{CO}_{2}$.

An estimate of the $\mathrm{CaCO}_{3}$ excess of the Baltic Sea compared to standard seawater is required for chemical composition models of seawater such as FREZCHEM (Feistel and Marion, 2007) which can be used to evaluate the calcium carbonate supersaturation in relation to atmospheric $\mathrm{CO}_{2}$ levels and its potential consequences (Marion et al., 2009; Comeau et al., 2009; Veron et al., 2009). Since the density anomaly of the Baltic Sea is varying on climatological time scales, the third aim of this paper is to provide a more recent anchor point for this model in relation to the extended similar investigation made forty years ago by Kremling (1969, 1970, 1972) and Millero and Kremling (1976).

The fourth aim of this paper is a conceptual one, related to the former ones. The different oceanographic salinity scales that are in use since 1902 are not metrologically traceable to SI units (Seitz et al., 2008). Both PSS-78 and the recent Reference-Composition Salinity Scale (Millero et al., 2008) are defined in terms of relative conductivity measurements with artefacts such as IAPSO ${ }^{2}$ Standard Seawater (SSW) or a potassium chloride solution used as a reference. Reliance on such artificial references introduces the risk of unnoticed or falsly indicated property changes over time or between different samples. It would therefore be preferable to establish traceability to the highly reliable and independently realisable standards of the International System of Units (Jones, 2009). The $\mathrm{SCOR}^{3} / \mathrm{IAPSO}$ Working Group 127 (WG127) on the Thermodynamics and Equation of State of Seawater

\footnotetext{
${ }^{2}$ IAPSO: International Association for the Physical Sciences of the Ocean, http://iapso.sweweb.net

${ }^{3}$ SCOR: Scientific Committee on Oceanic Research, http://www.scor-int.org
}

is currently developing a new concept for the measurement of Absolute Salinity based on SI-traceable density determinations (Wolf, 2008). The Baltic Sea with its strong density anomaly and pronounced trends in its properties is a prominent example of the need for the development of this approach and a useful testing ground for the new but yet immature calibration technology. For this reason, we have carried out comparison measurements of conductivity and density in an SI-traceable way and we report the results in this paper. The presentation of results is accompanied by selected chemical composition data.

The true Absolute Salinity is defined in terms of the mass fraction of dissolved material in seawater (Millero et al., 2008). As discussed by Millero et al., the precise definition requires the determination of equilibrium conditions at specified temperature and pressure and even with these additional qualifiers some ambiguity remains. In practice, measuring the mass fraction of dissolved material in seawater is even more difficult than defining it and approximate approaches must be used. It is the "Millero Rule" that says that the density of an aqueous solution is in good approximation a function of the Absolute Salinity, independent of the particular composition of the given mass of dissolved matter (Millero, 1974; Millero et al., 1978, 2008, 2009). Under this approximation, Baltic seawater and Standard Seawater have the same Absolute Salinity if they have the same density at given temperature and pressure. Thus, we can measure the density of Baltic seawater, and use the TEOS-10 equation of state to compute the Absolute Salinity of Standard Seawater with this density. We then use Millero's Rule and take this "density salinity" as an estimate for the mass of salt dissolved in the Baltic Sea sample. We note however that the true Absolute Salinity is defined as the mass ratio of dissolved material and that Millero's Rule provides an approximation to this quantity. Unfortunately, for seawater that is not of Reference Composition there is currently no method available to precisely measure the Absolute Salinity, but Millero's Rule provides an approximation that allows the density to be recovered to the measurement accuracy (due to the use of the "density salinity" to estimate Absolute Salinity) as well as a useful approximation for other thermodynamic quantities that can be determined from the TEOS-10 Gibbs function (IAPWS, 2008; IOC, 2010; Feistel et al., 2009; Wright et al., 2009).

\section{Salinity of standard and baltic seawater based on previous measurements}

Since the introduction of the Practical Salinity Scale, the electrolytic conductivity $C$ of a seawater sample is practically measured by salinometers or conductivity sensors, calibrated with respect to a certified IAPSO Standard Seawater reference. The measured conductivity ratio is converted to conductivity using $C=4.2914 \mathrm{~S} \mathrm{~m}^{-1}$ at $S_{\mathrm{P}}=35, t=15^{\circ} \mathrm{C}$ 
and $P=101325 \mathrm{~Pa}$ (Culkin and Smith, 1980; SeaBird, 1989) and from $C$, the temperature $T$ and the pressure $P$, Practical Salinity $S_{\mathrm{P}}$ is computed from the function (Perkin and Lewis, 1980)

$S_{\mathrm{P}}=s(C, T, P)$.

Over the range of concentrations where Practical Salinity is defined, it can be converted to Reference Salinity, $S_{\mathrm{R}}$, by the factor $u_{\mathrm{PS}}=\left(35.16504 \mathrm{~g} \mathrm{~kg}^{-1}\right) / 35$ (Millero et al., 2008, Feistel, 2008):

$S_{\mathrm{R}}=S_{\mathrm{P}} \cdot u_{\mathrm{PS}}$.

For Standard Seawater, $S_{\mathrm{R}}$ is the most accurate estimate currently available for the Absolute Salinity. Given $S_{R}$, the corresponding density estimate can be determined from the Gibbs function $g\left(S_{\mathrm{R}}, T, P\right)$ of seawater (Feistel, 2008; IAPWS, 2008; IOC, 2010):

$\rho=\frac{1}{g_{P}\left(S_{\mathrm{R}}, T, P\right)}$

Here, the subscript $P$ denotes the partial derivative with respect to the pressure, and $T$ and $P$ are the temperature and pressure at which the density is required, e.g. at laboratory conditions. $T$ and $P$ will be omitted from the equations below for simplicity. In the case of Standard Seawater, (Eq. 3) provides our best estimate of the true density, $\rho^{\mathrm{SSW}}$. In the case of Baltic seawater, (Eq. 3) yields an apparent density that is subject to significant error. The anomaly of the true Baltic seawater density relative to this rather uncertain estimate can be determined by measuring the true density, $\rho^{\mathrm{BSW}}$, with a vibration densitometer (Kremling, 1971; Millero and Kremling, 1976). The Absolute Salinity, $S_{\mathrm{A}}^{\mathrm{BSW}}=S_{\mathrm{R}}+\delta S_{\mathrm{A}}$, of Baltic seawater can then be estimated by the "density salinity", i.e., by computing the Absolute Salinity of Standard Seawater giving the measured density of Baltic seawater, from the formula (Millero et al., 2008),

$\rho^{\mathrm{BSW}}=\frac{1}{g_{P}\left(S_{\mathrm{R}}+\delta S_{\mathrm{A}}\right)} \approx \frac{1+\beta \cdot \delta S_{\mathrm{A}}}{g_{P}\left(S_{\mathrm{R}}\right)}$,

i.e., $\delta S_{\mathrm{A}}=\left(\rho^{\mathrm{BSW}} g_{P}-1\right) / \beta$. Here, $\beta=-g_{S P} / g_{P}$ is the haline contraction coefficient.

In Fig. 1, the anomaly $S_{\mathrm{A}}^{\mathrm{BSW}}-S_{\mathrm{R}}$ is shown as a function of $S_{\mathrm{R}}$ for 153 samples collected 40 years ago by Kremling $(1969,1970,1972)$, computed by means of (Eqs. 2-4) from the published values of measured Practical Salinity, $S_{\mathrm{P}}$, and the measured density,

The correlation relating "density salinity" to Practical Salinity is easily obtained since both Practical Salinity and density are easily measured on a regular basis. Based on Kremling's data, the regression line is

$$
\begin{aligned}
\delta S_{\mathrm{A}} & =S_{\mathrm{A}}-S_{\mathrm{R}}=0.00428 \cdot\left(S_{\mathrm{SO}}-S_{\mathrm{R}}\right) \\
& =150 \mathrm{mgkg}^{-1} \cdot\left(1-\frac{S_{\mathrm{R}}}{S_{\mathrm{SO}}}\right)
\end{aligned}
$$

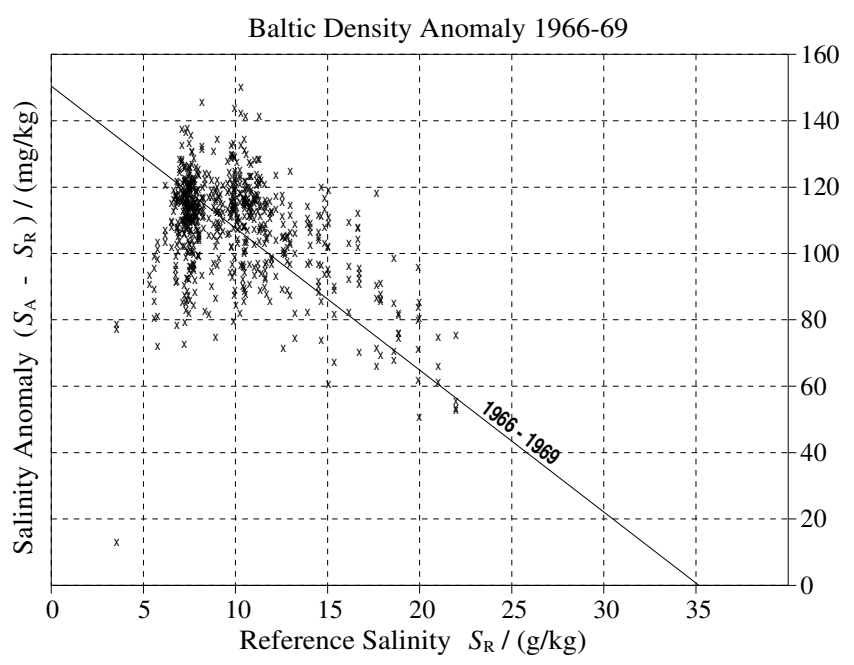

Fig. 1. Salinity anomaly $\delta S_{\mathrm{A}}=S_{\mathrm{A}}-S_{\mathrm{R}}$ computed by means of (Eqs. 2-4) from Practical Salinity and density data measured by Kremling (1969, 1970, 1972) and Millero and Kremling (1976) in the period 1966-1969. The sample near $S_{\mathrm{R}}=4 \mathrm{~g} / \mathrm{kg}$ with exceptionally low anomaly was excluded from the fit (Eq. 5); it was collected in the Vistula Estuary.

The fit was constrained to pass through $\left(S_{\mathrm{R}}=S_{\mathrm{SO}}, \delta S_{\mathrm{A}}=\right.$ 0 ) because the Atlantic water part of the brackish mixture is free of the Baltic anomaly (Millero and Kremling, 1976). Here, the standard-ocean salinity is $S_{\mathrm{SO}}=35 u_{\mathrm{PS}}=$ $35.16504 \mathrm{gkg}^{-1}$ (Millero et al., 2008).

The strong scatter visible in Fig. 1 at very low salinities is due to the inhomogeneous water properties caused by the very different loads of the many discharging rivers. The sampling is patchy, but adequate for the present purpose. The calcium carbonate that is primarily responsible for the Absolute Salinity anomalies is mainly carried by rivers draining the European lowlands, while the Scandinavian rivers flow over solid rocks and are subsaturated with respect to lime (Kwiecinski, 1965). Spatial distributions of the river water age (Meier, 2007) indicate weak lateral mixing of the properties between the various rivers which contributes to the spatial inhomogeneity of the Baltic surface water. In lowest order, the structure of the mean surface current is evident from the climatological horizontal salinity gradient, Fig. 2 (Feistel et al., 2008). The Baltic has a mean basin-scale circulation that is predominantly estuarine (vertical) rather than horizontal (see the schematic flow diagram in Fig. 10.1 of Matthäus et al., 2008, available at http://www2008.io-warnemuende. de/baltic2008/figures/figures_of_chapter_10.pdf). Precipitation and fresh riverine water is added to the surface, and over time the surface water is enriched with salt from below by entrainment. The diffusive transport of saline water into the Baltic from the North Sea is negligible and strongly dominated by the permanent upward salt transport through the halocline at about $60 \mathrm{~m}$ depth, which has been roughly estimated as $30 \mathrm{~kg} \mathrm{~m}^{-2} \mathrm{yr}^{-1}$, consistently from 


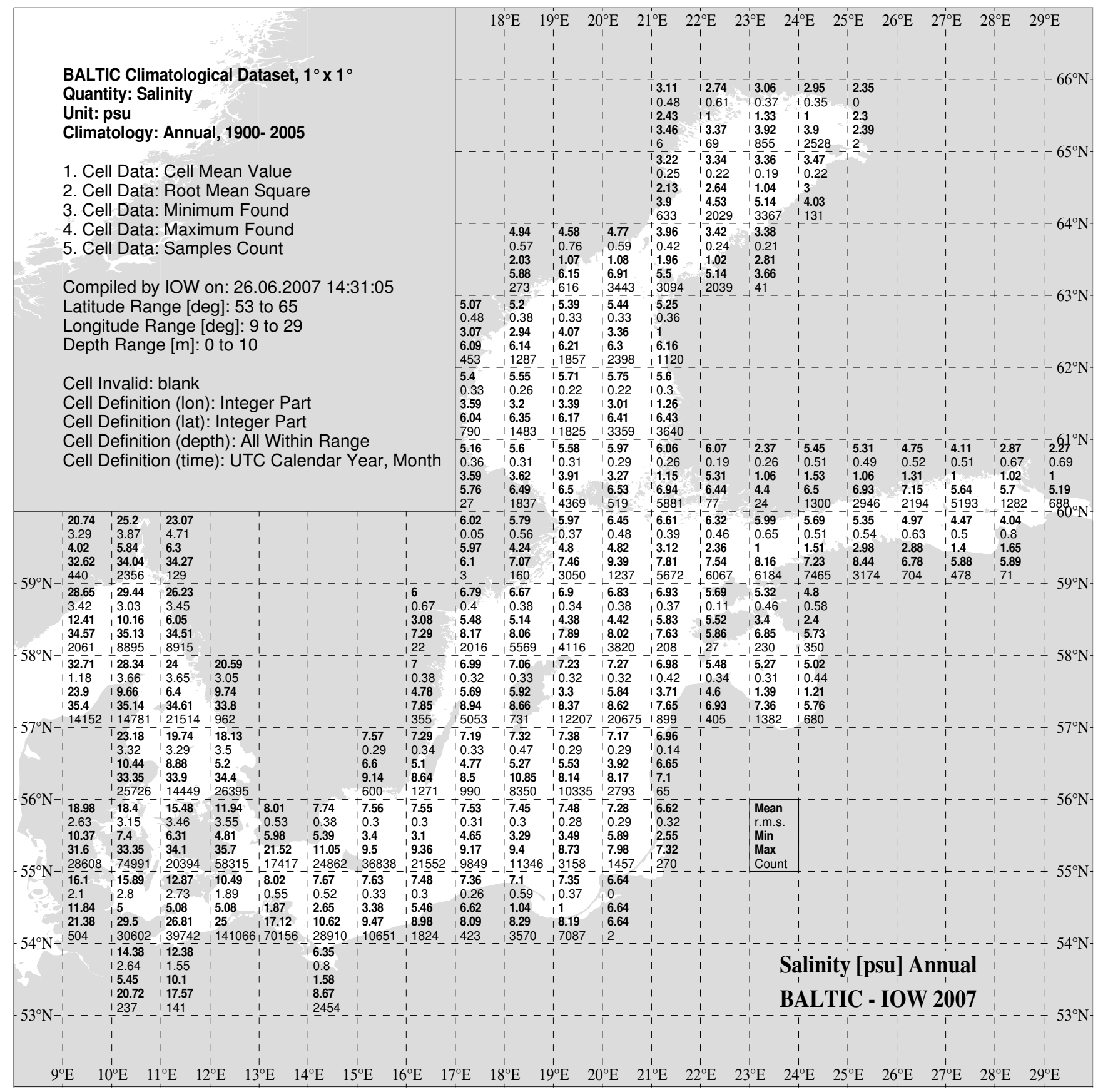

Fig. 2. Climatological surface distribution of Practical Salinity from the Baltic Atlas of Long-Term Inventory and Climatology (BALTIC, Feistel et al., 2008). For each grid cell of $1^{\circ} \times 1^{\circ} \times 10 \mathrm{~m}$ size, Practical Salinity values measured during 1900-2005 are represented by the mean value, the root-mean square (r.m.s.) deviation, the minimum and maximum values observed, as well as the total number of samples available (count). 
different approaches (Feistel et al., 2008; Reissmann et al., 2009). Consequently, the climatological surface salinity increases following the mean surface flow from the north-east to the south-west. Brackish surface water is present in the outflow branch of the Baltic "conveyor belt" that drives the Baltic Current along the Norwegian coast; saltier water from the North Sea is flowing in at the bottom. In the shallow Belt Sea, strong mixing occurs between the inflowing and outflowing layers that implies a recirculation of significant freshwater fractions as a part of the salty bottom water.

In addition to the salt, entrainment from below the pycnocline adds aged, mixed and possibly chemically transformed riverine solutes to the surface layer (Reissmann et al., 2009). In the deep water of the estuarine Baltic Sea environment, the dissolved species may be subjected to either reducing or oxidizing conditions that are sustained for extended periods of time (Nausch et al., 2008). The time scales associated with these processes are of the order of decades (Stigebrandt and Wulff, 1989; Meier et al., 2006; Feistel et al., 2008).

In the special case in which the stoichiometric deviation from the Reference Composition is caused by an excess of non-conducting solutes with low concentrations, the value of $S_{\mathrm{R}}$ represents the mass fraction of sea salt with Reference Composition in the sample, and $\delta S_{\mathrm{A}}$ represents the anomalous mass fraction of non-conducting species, at least to a practically reasonable accuracy. This can safely be assumed for the silicate anomaly in the North Pacific (McDougall et al., 2009), but it is not generally the case in the Baltic Sea since the additional $\mathrm{CaCO}_{3}$ dissociates and increases the conductivity by a non-zero amount, evidently less than what would result from adding the same mass of sea salt that has Reference Composition. Similarly, the algorithms used to estimate Practical Salinity at temperatures and pressures different from $15^{\circ} \mathrm{C}$ and $101325 \mathrm{~Pa}$ are not valid in the presence of the composition anomalies and (Eq. 1) results in inconsistent estimates, which can result in the appearance that the salinity is not conservative when subjected to temperature or pressure changes. Consequently, the correlation shown in Fig. 1 may look different depending on the particu$\operatorname{lar} T$ or $P$ at which the measurements were carried out in the lab. However, a study dedicated to this problem (Feistel and Weinreben, 2008) came to the conclusion that these apparent non-conservation effects for Baltic seawater do not exceed the measurement uncertainty over a reasonable temperature interval at atmospheric pressure. Consequently, the parameterisation of the Absolute Salinity of Baltic Sea water as a function of Reference Salinity is stable with respect to temperature variations at atmospheric pressure and is thus justified for application in the context of TEOS-10 (IOC, 2010).

The above approach to estimating Absolute Salinity relies on an empirical relation between Absolute and Practical Salinity in the Baltic Sea. It does not permit the separate estimation of the contributions from riverine input into the Baltic Sea and from the sea salt flowing in from the Atlantic. This separation is possible using measurements of the chlo- rinity, $\mathrm{Cl}$, rather than conductivity since no relevant amounts of chlorine, bromine or iodine are discharged from the tributaries. Chlorinity can thus be used to estimate the Absolute Salinity contribution associated with input from the Atlantic and subtracting this value from the density salinity will provide an estimate of the contribution associated with local inputs. Millero and Kremling (1976) performed their correlation analysis based on chlorinity data. Two drawbacks of this method are that chlorinity is not a concentration measure to be used with TEOS-10, and silver titrations are not carried out regularly on modern research or monitoring cruises in the Baltic. Nevertheless, the approach can be used to separate the salt inputs from the Atlantic and from local runoff and to provide a comparison with the conditions found earlier by Knudsen (1901) and Sørensen (Forch et al., 1902).

For Standard Seawater, the Reference Salinity $S_{\mathrm{R}}$ can be computed from the chlorinity by multiplying by the factor $u_{C l}=1.80655 \cdot u_{\mathrm{PS}}$ (Millero et al., 2008; Feistel, 2008). For Baltic Sea water the result will differ from $S_{\mathrm{R}}$, and is therefore referred to here as "chlorinity salinity", $S_{C l}$ :

$S_{C l}=C l \cdot u_{C l}=180655 \cdot C l \cdot u_{\mathrm{PS}}$

Using the chlorinity, $\mathrm{Cl}$, and the density, $\rho^{\mathrm{BSW}}$, data measured by Kremling $(1969,1970,1972)$ and Millero and Kremling (1976) together with (Eq. 4) in the form,

$\rho^{\mathrm{BSW}}=\frac{1}{g_{P}\left(S_{C l}+\delta S^{\mathrm{RI}}\right)} \approx \frac{1+\beta \cdot \delta S^{\mathrm{RI}}}{g_{P}\left(S_{C l}\right)}$,

the regression line for the river input, $\delta S^{\mathrm{RI}}$, Fig. 3 , is determined as

$$
\begin{aligned}
\delta S^{\mathrm{RI}} & =S_{\mathrm{A}}-S_{C l}=000492 \cdot\left(S_{\mathrm{SO}}-S_{C l}\right) \\
& =173 \mathrm{mgkg}^{-1} \cdot\left(1-\frac{S_{C l}}{S_{\mathrm{SO}}}\right) .
\end{aligned}
$$

The difference between (Eqs. 5 and 8 ) is caused by the fact that the riverine input includes calcium carbonate and other solutes which alter the impact on the electrical conductivity compared to the effect of diluting with pure water whereas the riverine input includes no corresponding input of halides. Because of this latter fact, the intercept at $S_{C l}=0$ corresponds to no contribution from North Atlantic water and provides a direct estimate of the contribution to Absolute Salinity due to the salt content of the local riverine inputs.

Millero and Kremling (1976) did an analogous fit to their data set with 153 samples but found an intercept at zero chlorinity of only $S_{\mathrm{A}}^{0}=124 \mathrm{mgkg}^{-1}$. The reason for this difference is probably the older equation of state used at that time (F. J. Millero, personal communication, 2009).

It is also possible to estimate the relation corresponding to (Eq. 8) based on data from the early 20th century. The Knudsen (1901) Equation $S_{\mathrm{K}}=0.03 \mathrm{gkg}^{-1}+1.805 \mathrm{Cl}$, was calculated from Sørensen's analysis of 9 surface water samples, including 6 from the Baltic Sea, in particular, one from the Gulf of Finland, one from Gulf of Bothnia, two from the 


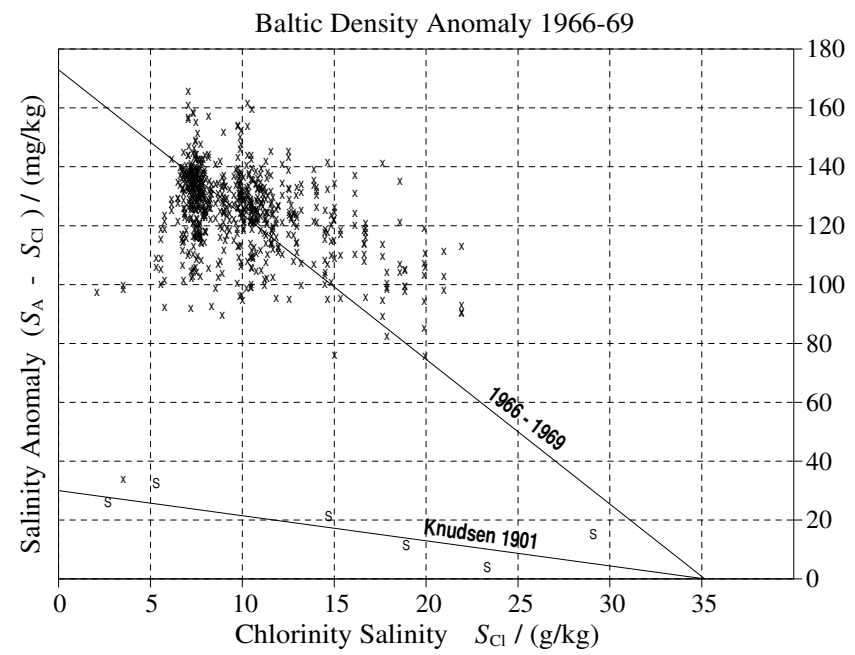

Fig. 3. Salinity anomaly associated with local runoff $\delta S_{C l}=S_{\mathrm{A}}-$ $S_{C l}$ computed by means of (Eqs. 4-6) from chlorinity and density data, symbol "x", measured by Kremling $(1969,1970,1972)$ and Millero and Kremling (1976) in the period 1966-1969. The sample with exceptionally low anomaly collected in the Vistula Estuary was excluded from the fit (Eq. 7) giving the line indicated by "1966-1969". The "Knudsen 1901" (Eq. 9) was derived by Knudsen (1901) from the measurements of Sørensen (Forch et al., 1902), Table 1, shown as symbol "S" in the diagram.

Great Belt and two from the Kattegat (Forch et al., 1902), which are reported for easy reference in Table 1.

The numerical value of $S_{\mathrm{K}}$ in $\mathrm{g} / \mathrm{kg}$ or $\%$ o coincides with Practical Salinity (only) at $S_{\mathrm{P}}=35$ which was used by PSS-78 to specify the coefficient relating $S_{\mathrm{P}}$ to $\mathrm{Cl}$. Converting the chlorinity to a salinity estimate using (Eq. 6), $S_{C l}=C l \cdot u_{C l}$, effectively gives the Absolute Salinity of Standard Seawater with this chlorinity. In addition, the absolute Knudsen salinity, $S_{\mathrm{K}}$, can be corrected for the loss of volatile substances such as $\mathrm{HCl}$ using the factor relating Practical Salinity to Reference-Composition Salinity, thus providing an improved estimate of the true Absolute Salinity, $S_{\mathrm{A}}=S_{\mathrm{K}} /\left(\mathrm{gkg}^{-1}\right) \cdot u_{\mathrm{PS}}$. Using these two relations, the 1901 equation reads

$$
S_{\mathrm{A}}-S_{C l}=000086 \cdot\left(S_{\mathrm{SO}}-S_{C l}\right)=30 \mathrm{mgkg}^{-1} \cdot\left(1-\frac{S_{C l}}{S_{\mathrm{SO}}}\right) .
$$

The uncertainties associated with this formula are unknown, but probably quite large due to the small number of data inputs used to derive Knudsen's formula. Nevertheless, the slope and the intercept corresponding to the Knudsen equation are significantly lower than the more recent values, Fig. 3. Since the intercept at $S_{C l}=0$ provides an estimate of the "density salinity" of local riverine inputs, this seems to indicate that the calcium carbonate content of these inputs increased significantly between the end of the 19th century and 1970. In a similar regression, Ohlson and Anderson (1990)

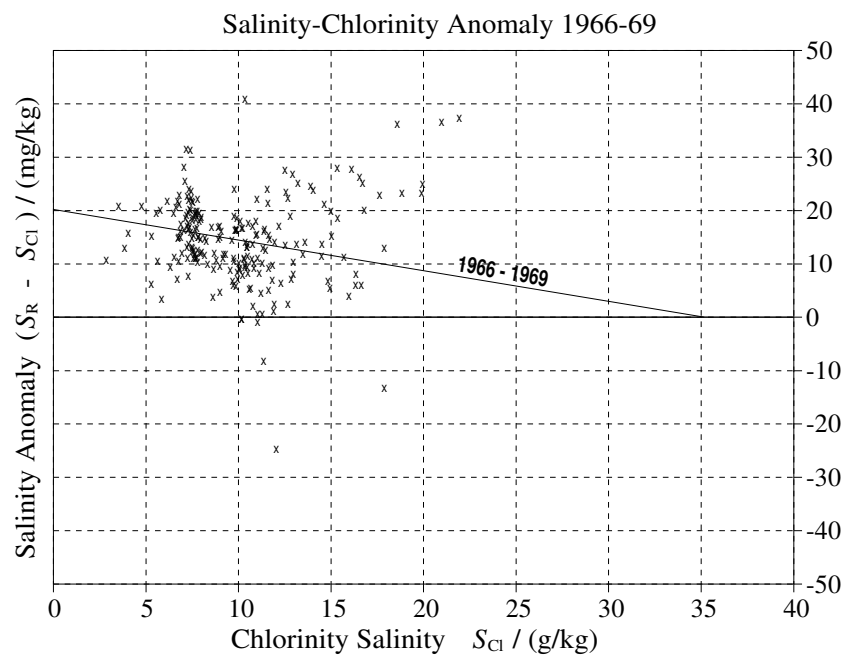

Fig. 4. Deviation between the Reference Salinity (Eq. 2), $S_{\mathrm{R}}$, and the chlorinity salinity (Eq. 6), $S_{C l}$, computed from Kremling's data collected between 1966 and 1969. Note that this relation does not account for the additional contribution to Absolute Salinity given by (Eq. 5) and illustrated in Fig. 1. The regression line (Eq. 10) quantifies the average conductivity of the riverine water.

calculated the riverine calcium concentration rising from $521 \mu \mathrm{M}$ (1938) to $571 \mu \mathrm{M}$ (1967) and $878 \mu \mathrm{M}$ (1986), which correspond to approximately 52,57 and $88 \mathrm{mg} / \mathrm{kg}$ in terms of $\mathrm{CaCO}_{3}$, respectively. $\mathrm{M}$ used to be the unit of amountof-substance-concentration (molarity); its use is discouraged within the SI system. The results of Kremling and Wilhelm (1997) indicate that this increase continued between 1970 and 1995.

The relation between salinity, electrolytic conductivity and chlorinity in the Baltic Sea is not as well understood as for Standard Seawater (Millero et al., 2008). Kremling $(1969,1970,1972)$ calculated separate correlation equations between measured pairs of chlorinity and Practical Salinity values for different subsets of his data; the salinity intercepts at zero chlorinity varied between 0.023 and 0.041. The difference between Reference Salinity (Eq. 2) and chlorinity salinity (Eq. 6) for Kremling's data is displayed in Fig. 4 as a scatter plot. The regression line is given by,

$$
S_{\mathrm{R}}-S_{C l}=000058 \cdot\left(S_{\mathrm{SO}}-S_{C l}\right)=20 \mathrm{mgkg}^{-1} \cdot\left(1-\frac{S_{C l}}{S_{\mathrm{SO}}}\right) .
$$

In the absence of ocean water, $S_{C l}=0$, (Eq. 10) indicates a residual Reference Salinity of $S_{\mathrm{R}}=20 \mathrm{mg} / \mathrm{kg}$. Dividing by $u_{\text {PS }}$ to convert to Practical Salinity and then using standard algorithms to invert (Eq. 1) gives an average conductivity of about $C \approx 2.7 \mathrm{mSm}^{-1}$ for the Baltic river waters at $20^{\circ} \mathrm{C}$.

In a systematic study, Kwiecinski (1965) found that although the anomalous temporal or regional increase in the Practical Salinity usually follows that of calcium, there is no constant relation between them, and that additional factors such as the $\mathrm{pH}$, the alkalinity or the dissolution of $\mathrm{CO}_{2}$ may 
Table 1. Samples collected from the Baltic Sea in 1900 and analysed by Sørensen (Forch et al., 1902). It may be the extreme effort of salinity determination by drying at $150-480^{\circ} \mathrm{C}$ over $120 \mathrm{~h}$ that prevented Sørensen from the analysis of all available samples. Additional samples taken from outside the Baltic Sea are omitted from this table.

\begin{tabular}{crrrrrrc}
\hline Sample & Cl\%o & $S_{\mathrm{K}} \%$ No & N. Lat. & E. Lon. & Depth m & Date, Time & Sea \\
\hline & & & & & & & \\
$\# 32$ & 1.4736 & 2.688 & $60^{\circ} 07^{\prime}$ & $28^{\circ} 33.5^{\prime}$ & 0 & 19 July 1900, 20:50 & G. Finland \\
$\# 33$ & 2.9274 & 5.321 & $62^{\circ} 07^{\prime}$ & $20^{\circ} 02^{\prime}$ & 0 & 24 July 1900, 15:00 & G. Bothnia \\
$\# 29$ & 4.6075 & & $54^{\circ} 39.5^{\prime}$ & $12^{\circ} 17.3^{\prime}$ & 0 & 7 May 1900, 08:00 & Belt Sea \\
$\# 30$ & 8.0888 & 14.634 & $55^{\circ} 42.2^{\prime}$ & $10^{\circ} 43.7^{\prime}$ & 0 & 8 May 1900, 14:10 & Gr. Belt \\
$\# 9$ & 10.4102 & 18.818 & $55^{\circ} 52^{\prime}$ & $10^{\circ} 52^{\prime}$ & 0 & 23 April 1900, 18:00 & Gr. Belt \\
$\# 10$ & 12.8422 & 23.204 & $56^{\circ} 53^{\prime}$ & $11^{\circ} 07^{\prime}$ & 0 & 26 April 1900, 18:15 & Kattegat \\
$\# 25$ & 16.0200 & 28.956 & $57^{\circ} 38^{\prime}$ & $10^{\circ} 46^{\prime}$ & 0 & 27 April 1900, 09:00 & Kattegat \\
$\# 28$ & 5.837 & & $54^{\circ} 40^{\prime}$ & $11^{\circ} 58^{\prime}$ & 0 & 7 May 1900, 14:00 & Belt Sea \\
$\# 7$ & 10.117 & & $56^{\circ} 15^{\prime}$ & $12^{\circ} 26^{\prime}$ & 0 & 19 April 1900, 12:00 & Kattegat \\
$\# 8$ & 10.873 & & $56^{\circ} 30.5^{\prime}$ & $12^{\circ} 09^{\prime}$ & 0 & 19 April 1900, 14:00 & Kattegat \\
$\# 12$ & 14.295 & & $57^{\circ} 04^{\prime}$ & $10^{\circ} 49^{\prime}$ & 0 & 26 April 1900, 20:00 & Kattegat \\
$\# 11$ & 17.895 & & $56^{\circ} 08^{\prime} 9$ & $11^{\circ} 11^{\prime} 2$ & 27.3 & 23 April 1900, 20:30 & Gr. Belt \\
Swedish & 18.780 & & $57^{\circ} 44^{\prime}$ & $11^{\circ} 22^{\prime}$ & 72 & 21 March 1900 & Kattegat \\
\hline
\end{tabular}

be important. Numerical composition models (Anderko and Lencka, 1997; Feistel and Marion, 2007; Pawlowicz, 2008, 2009) may provide more detailed insight in the future. The composition of the Baltic Sea salt measured by different authors was summarized by Nehring (1980) as given in Table 2 in comparison to the Reference Composition (Millero et al., 2008).

\section{Experimental methods used for recent measurements}

In this Sect. the experimental methods and uncertainties are described with regard to the samples collected from the Baltic Sea during the period 20062009. Results of the measurements are reported in the digital Supplement (http://www.ocean-sci.net/6/3/2010/ os-6-3-2010-supplement.zip) of this paper.

\subsection{Sample collection}

The Baltic Sea water samples were collected from 2006 to 2009 at the positions shown in Fig. 5. The bottle depth ranged between the surface and $400 \mathrm{~m}$. A total of 438 samples were analysed.

On the vessel, most of the samples were extracted into Duran-glass bottles (volume: $100 \mathrm{ml}$ ) by means of a CTD SBE-911 rosette equipped with IOW-freeflow samplers. Only the samples from the stations "FYxx" were collected from the cooling water inlet of the ferry and extracted into PET plastic bottles.

\subsection{Routine salinometer and density measurements}

For the determination of Practical Salinity, salinometers of the type AUTOSAL 8400B (Guildline Instruments, Canada) were used. Measurements of Practical Salinity were performed according to the rules of WOCE Operations and Methods (Stalcup, 1991). Once a day the salinometer was first adjusted with IAPSO Standard Seawater (SSW) and the SSW density was then determined with the densitometer.

The results of the density measurements of Standard Seawater are shown in Fig. 6. The deviations from zero must be attributed to the stability of the SSW samples and the measuring technique. The calculations refer to the Practical Salinity value given on the ampoule's label. Practical Salinity measurements could not be done because the SSW samples were used for the calibration of the salinometer. For SSW (only $\mathrm{P}$-series) we found a mean value of the difference $\delta \mathrm{S}_{\mathrm{A}}$ of $-4.2 \mathrm{mg} / \mathrm{kg}$ with a standard deviation of $2.1 \mathrm{mg} / \mathrm{kg}$. There is a slight dependence on the age of the sample. The related regression is line is

$\delta S_{\mathrm{A}} /(\mathrm{mg} / \mathrm{kg})=0.0032 d-6.1453$,

where $d$ is the age of the samples in days. For SSW (10Lseries) the distribution and number of measurements was inadequate for reliable regression results to be obtained.

Measurements of the density were done by means of a densitometer DMA 5000 (Anton Paar, Austria). The device was calibrated daily with air and pure water. Measurements of the density and salinity were carried out at the same time as soon as possible after collecting the samples on board, or after returning to IOW's laboratory. If the time that passed between collection and analysis of the samples was longer than one day, the samples were stored in a dark and cool place. 
Table 2. Ratios $r_{\mathrm{X}}=w(\mathrm{X}) / C l$ of mass fractions $w(\mathrm{X})$ to chlorinity $\mathrm{Cl}$ of the main sea salt constituents $\mathrm{X}$ compiled by Millero et al. (2008) for Standard Seawater and by Nehring (1980) for Baltic seawater from different sources. Molar masses $A_{\mathrm{X}}$ are those compiled by Millero et al. (2008). The oceanic value of $r_{\mathrm{Cl}}=\left[1 /\left(0.3285234 A_{\mathrm{Ag}}\right)-r_{\mathrm{Br}} / A_{\mathrm{Br}}\right] \cdot A_{\mathrm{Cl}}$ is inferred from the definition of chlorinity, using the molar mass $A_{\mathrm{Ag}}=107.8682(2) \mathrm{g} / \mathrm{mol}$ of silver. The Baltic $r_{\mathrm{Cl}}$ is calculated from the same formula using Kremling's value for $r_{\mathrm{Br}}$. The numbers in brackets are the standard uncertainties of the corresponding digit (s) in front of the opening bracket.

\begin{tabular}{|c|c|c|c|c|}
\hline $\begin{array}{l}\text { Solute } \\
\mathrm{X}\end{array}$ & $\begin{array}{l}\text { Molar Mass } \\
\mathrm{g} / \mathrm{mol} A_{\mathrm{X}}\end{array}$ & $\begin{array}{l}\text { Reference } \\
\text { Composition } r_{X}\end{array}$ & $\begin{array}{l}\text { Baltic Sea } \\
r_{X}\end{array}$ & Baltic Sea Source \\
\hline $\mathrm{Na}$ & $22.98976928(2)$ & 0.5564924 & $\begin{array}{l}0.5549-0.5562 \\
0.5554 \\
0.5547(21)\end{array}$ & $\begin{array}{l}\text { Zarins and Ozolins (1935) } \\
\text { Culkin and Cox (1966) } \\
\text { Kremling (1969) }\end{array}$ \\
\hline$K$ & $39.0983(1)$ & 0.0206000 & $\begin{array}{l}0.0200 \\
0.0205 \\
0.0206(6)\end{array}$ & $\begin{array}{l}\text { Zarins and Ozolins (1935) } \\
\text { Culkin and Cox (1966) } \\
\text { Kremling (1969) }\end{array}$ \\
\hline $\mathrm{Mg}$ & $24.3050(6)$ & 0.0662600 & $\begin{array}{l}0.06692 \\
0.0674(4) \\
0.067(3)\end{array}$ & $\begin{array}{l}\text { Voipio (1957) } \\
\text { Nehring and Rohde }(1967) \\
\text { Kremling }(1969,1970,1972)\end{array}$ \\
\hline $\mathrm{Ca}$ & $40.078(4)$ & 0.0212700 & & \\
\hline $\mathrm{Sr}$ & $8.762(1)$ & 0.0004100 & & \\
\hline $\mathrm{Ca}+\mathrm{Sr}$ & & 0.0216800 & $\begin{array}{l}0.0225-0.0268 \\
0.0218-0.0273\end{array}$ & $\begin{array}{l}\text { Rohde (1966) } \\
\text { Nehring and Rohde }(1967) \\
\text { Kremling }(1969,1970,1972)\end{array}$ \\
\hline $\mathrm{Cl}$ & $35.453(2)$ & 0.9989041 & 0.9989409 & \\
\hline $\mathrm{SO}_{4}$ & $96.0626(50)$ & 0.1400000 & $\begin{array}{l}0.1410 \\
0.1413(19) \\
0.1436(42) \\
0.1406(10)\end{array}$ & $\begin{array}{l}\text { Zarins and Ozolins (1935) } \\
\text { Kwiecinsky (1965) } \\
\text { Trzosinska }(1967) \\
\text { Kremling }(1969,1970,1972)\end{array}$ \\
\hline $\mathrm{CO}_{2}$ & $44.0095(9)$ & 0.0000220 & & \\
\hline $\mathrm{Br}$ & $79.904(1)$ & 0.0034730 & $\begin{array}{l}0.00329-0.00349 \\
0.00339(6)\end{array}$ & $\begin{array}{l}\text { Morris and Riley }(1966) \\
\text { Kremling }(1969,1970,1972)\end{array}$ \\
\hline B & $10.811(7)$ & & $0.00025(2)$ & Kremling $(1969,1970,1972)$ \\
\hline $\mathrm{B}(\mathrm{OH})_{3}$ & $61.8330(70)$ & 0.0010030 & & \\
\hline $\mathrm{B}(\mathrm{OH})_{4}$ & $78.8404(70)$ & 0.0004100 & & \\
\hline $\mathrm{F}$ & $18.9984032(5)$ & 0.0000670 & $0.000078(4)$ & Kremling $(1969,1970,1972)$ \\
\hline
\end{tabular}

Because of the strong stratification in the Baltic Sea it must be assumed that the content of a $5 \mathrm{~L}$-freeflow sampler is not necessarily homogeneous. For better results, 3 Duran bottles were filled. The measurements of salinity and density were done with seawater from the same glass bottle. Before the measurements were made, the bottle temperatures were adjusted to the room temperature (circa $23^{\circ} \mathrm{C}$ ). After uncapping the bottle a $20 \mathrm{ml}$ disposable syringe was filled for the density measurements. Then the bottle was fitted with an adapter for a peristaltic pump. A peristaltic pump was connected to the salinometer for measuring the salinity of the sample.
High precision density measurements require very careful handling and elaborate procedures. To reduce the measurement uncertainty a procedure similar to that described by Wolf (2008) was used. Measurements were performed in the following order: with pure water ( 3 measurements), with the sample A (6 measurements), the sample B (6 measurements), and again with pure water (3 measurements). The formation of air bubbles inside the measuring cell was a severe problem that had to be solved. Baltic Sea water has typical in-situ temperatures below the measuring temperature of the densitometer, $20^{\circ} \mathrm{C}$. Because of the reduced gas solubility, the samples tend to form air bubbles in the oscillator 


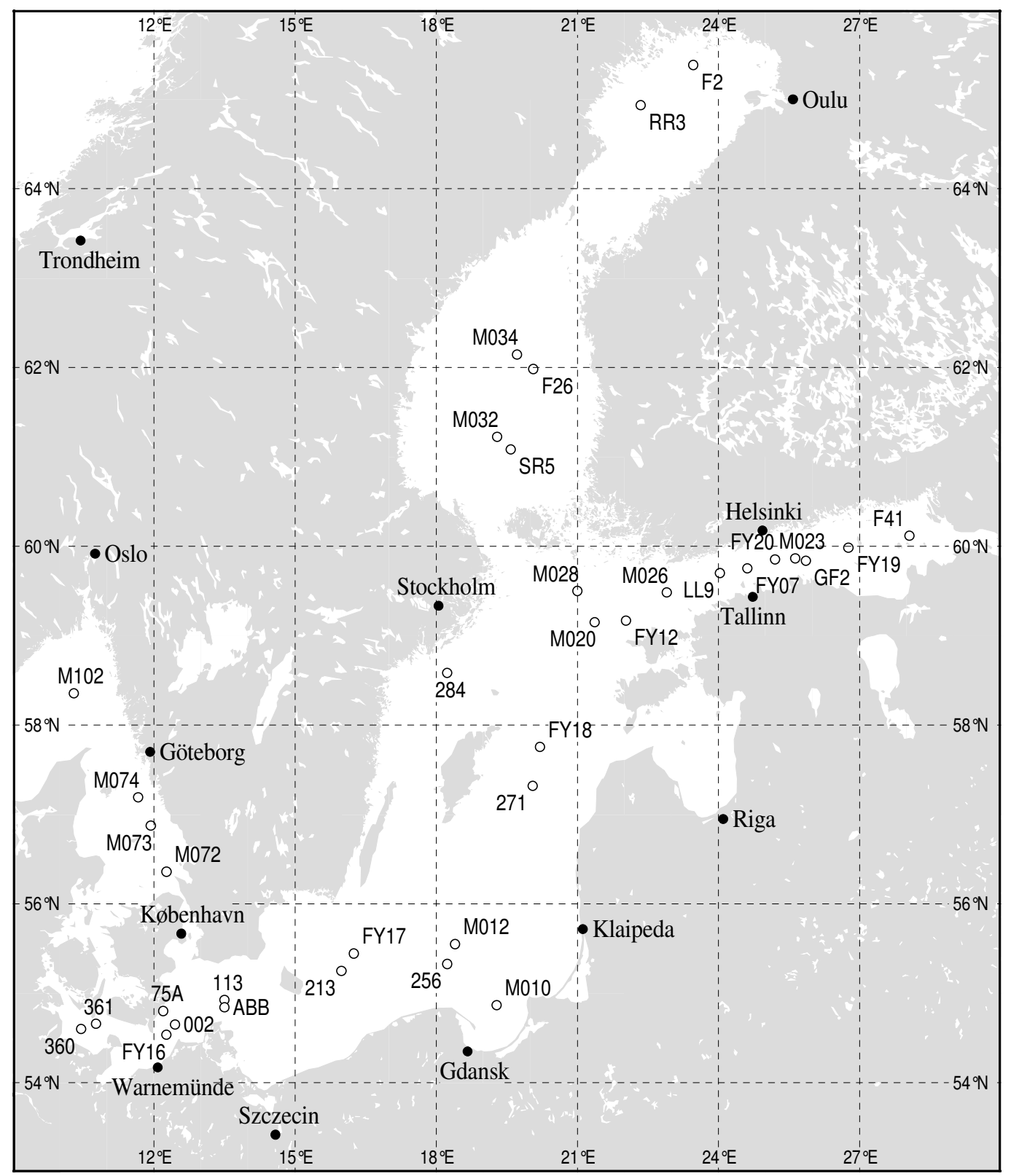

Fig. 5. Positions where the recent samples used for this paper were collected. Stations "Mxxx" are from cruise AL 322 of r/v "Alkor" in March 2009 and stations "FYxx" are from the ferry line "Finlandia" Travemünde-St. Petersburg in November 2008. "75A" was visited by r/v "Prof. A. Penck" on the research and monitoring cruise 40/06/20 in August 2006, observing a baroclinic inflow (Matthäus et al., 2008). The remaining stations north of $59^{\circ} \mathrm{N}$ are from cruise Combine $1 \mathrm{of} r / \mathrm{v}$ "Aranda" in January 2009 and the remaining stations south of $59^{\circ} \mathrm{N}$ are from regular IOW monitoring cruises 2006-2008. Shorelines are from RANGS (Feistel, 1999).

which lead to significant errors in the readings. As a special procedure, the syringe to be filled was equipped with a hypodermic needle. After insertion into the sample the plunger of the syringe was pulled back rapidly. The limited filling rate through the narrow needle forced a low pressure in the syringe and produced air bubbles in the syringe. These air bubbles were pushed outside. Then the syringe was attached to the inlet of the densitometer and one half of the content was pushed into the measuring cell. Three measurements were carried out and thereafter a further quarter of the syringe volume was pressed inside and three additional measurements were done.

To investigate the influence of suspended particles, a large fraction of the samples were measured with and without a polycarbonate syringe filter $(0.2 \mu \mathrm{m})$. The comparison of the measurements of filtered and unfiltered samples is shown in Fig 7. The influence of the filtration is not easy to determine because the two samples were stored in different flasks. The 


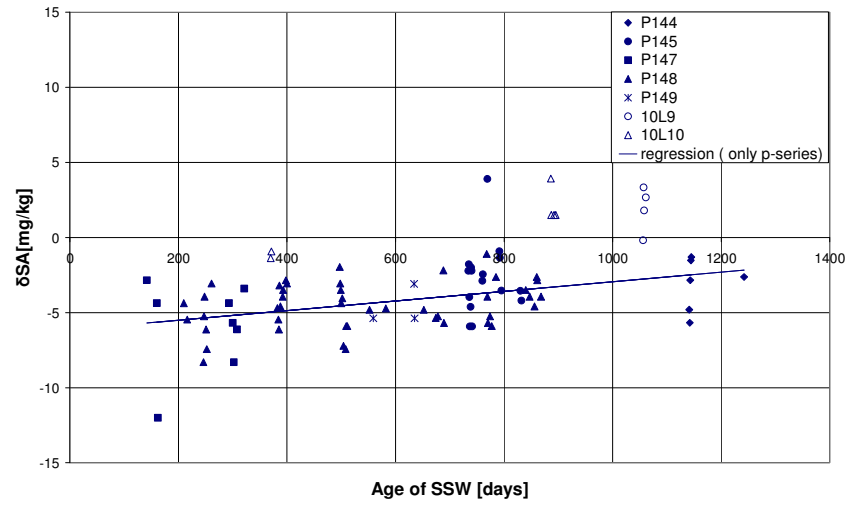

Fig. 6. Results of density measurements on standard seawater. Each data point represents a measurement of one bottle of SSW. P144 to P149 are batches of SSW with $S_{\mathrm{P}}=35$ and 10L9 and 10L10 are batches with $S_{\mathrm{P}}=10$. On the ordinate, the apparent salinity anomaly is shown, computed from (4), as a function of the sample age, in days.

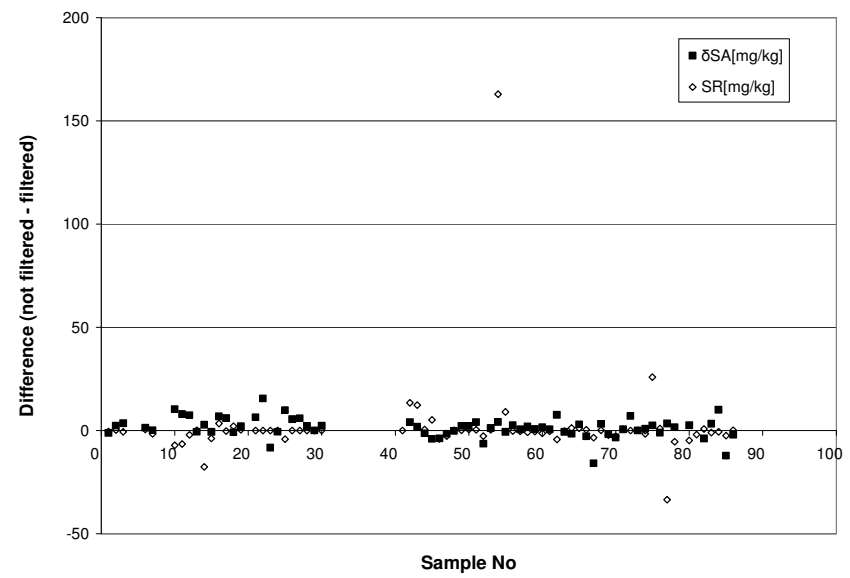

Fig. 7. Results of the comparison between filtered and unfiltered samples from the Baltic Sea. The particular pairs of samples were collected from the same CTD bottle but filled into separate flasks, subsequently. The symbols used together with the units are shown in the inset.

flasks were collected from the same water bottle of the CTD rosette. But this does not automatically imply that the water of both flasks has the same properties because the water in the bottle is usually stratified. Thus the shown difference of $\delta S_{\mathrm{A}}$ between unfiltered and filtered samples depends not only on the influence of filtration but also on the slightly different intrinsic properties of the two samples. We found a mean value of the difference of $\delta S_{\mathrm{A}}$ of $1.4 \mathrm{mg} / \mathrm{kg}$ with a standard deviation of $4.9 \mathrm{mg} / \mathrm{kg}$. For comparison, the differences of $S_{\mathrm{R}}$ are additionally displayed in Fig. 7. The mean value of the differences of $S_{\mathrm{R}}$ is $1.7 \mathrm{mg} / \mathrm{kg}$ with a standard deviation of $20.4 \mathrm{mg} / \mathrm{kg}$.

\section{3 "Absolute" conductivity}

Although the concept of an "absolute" measurement makes no sense from a strict metrological point of view, we will use this term for convenience to distinguish the measurements discussed here from those described in the previous section. Every quantity value that is indicated by a measuring device is inherently relative, since it is inevitably referred to something. Therefore metrological terminology prefers talking about traceability of a measurement result (VIM, 2008). This concept characterises the quantitative link between the indicated result and the quantity value that has been assigned to an agreed standard by a measurement or production procedure. The link is established by calibration measurements. In this sense the commonly measured conductivity ratio used to calculate Practical Salinity is traceable to the $K_{15}$ ratio, which is indicated on Standard Seawater (SSW) ampoules used for device calibration. $K_{15}$ is the ratio of the electrical conductivity of the seawater sample, at a temperature (IPTS-68) of $15^{\circ} \mathrm{C}$ and a pressure of $101325 \mathrm{~Pa}$, to that of a potassium chloride $(\mathrm{KCl})$ solution, in which the mass fraction of $\mathrm{KCl}$ is $32.4356 \mathrm{~g} / \mathrm{kg}$ at the same temperature and pressure. The production procedure for SSW according to PSS78 , which in particular links the electrolytic conductivity of SSW to that of the defined potassium chloride solution, must be seen as the corresponding primary procedure to realize $K_{15}$. In contrast, an "absolute" conductivity measurement result must be understood as traceable to the quantity value of a primary standard of the International System of Units (SI), which is realized by a primary measurement procedure. In the following we will use the expression "absolute" as a shorthand expression for this important concept of traceability.

A measuring system for absolute electrolytic conductivity $C$ calculates it from a conductance measurement of a conductivity measuring cell that is filled with the solution under investigation:

$C=K \cdot G$

$K$ is the so called cell constant (not to be confused with the conductivity ratio $K_{15}$ of SSW). Commercial conductivity meters typically measure the conductance $G$ with respect to an (arbitrary) internal reference. In order to calculate absolute conductivity, therefore $K$ is determined by a calibration using a reference solution of known absolute conductivity. In contrast, in a primary conductivity measurement method, under the condition of a specific cell design, $K$ is determined by geometric measurements, while $G$ is deduced from measured impedance spectra (Brinkmann et al, 2003). Since all quantities are measured traceable to the SI, this method allows for the realization of primary conductivity standards whose conductivity values are consequently traceable to the SI, too. Note that conductivity is usually indicated at a defined temperature $T_{0}$. Thus the actual temperature $T$ of the solution 
during the measurement is also measured and the measured conductivity value is corrected to $T_{0}$.

In the present study we used the primary measurement method of the Physikalisch-Technische Bundesanstalt (PTB) (Brinkmann et al, 2003) to measure the absolute conductivity $C_{\mathrm{S}}$ of three samples from stations $361, \mathrm{ABB}$ and 213 , Fig. 5. After arrival, the samples were stored under cold and dark conditions. Prior to measurement the samples and the conductivity measuring cell were brought to a set temperature of $15^{\circ} \mathrm{C}$ (ITS-90) over night in a temperature bath. We additionally measured the absolute conductivities $C_{\mathrm{SSW}}$ of IAPSO SSW/P-series (batch P149) and 10L10-series (Practical Salinity 9.926, dated 14 June 2006) and calculated the conductivity ratio

$R_{15}=\frac{C_{\mathrm{S}}}{C_{\mathrm{SSW}}} K_{15}$

of the samples under investigation in order to scale the absolute conductivity measurement results to PSS-78. $K_{15}$ ratios were taken from the SSW ampoules (0.99984 for P-series and 0.31712 for L10-series). Conductivity values have been linearly corrected to $15^{\circ} \mathrm{C}$ (IPTS-68) using a temperature coefficient of $1.97 \% / K$. Finally we calculated Practical Salinity from the PSS-78 formula (Perkin and Lewis, 1980). The uncertainty of the absolute conductivity results includes contributions from the determination of temperature, conductance and the cell constant, and accounts for the statistical spread of the indicated values. Uncertainty propagation was calculated according to GUM (2008).

\subsection{High-accuracy density measurements}

Highly accurate density measurements at the PTB Braunschweig were performed for comparison with an oscillationtype density meter (Anton Paar DMA 5000) using a substitution method (Wolf, 2008). In a substitution method the sample to be measured and a reference sample are measured alternately several times. This method decreases the measurement uncertainty considerably as contributions to the uncertainty are mostly correlated and thus vanish when looking for the difference between sample and reference.

The reference liquid was ultra pure degassed water. The deviation of its density from seawater is below 3\%; thus, a very good correlation of the measurements performed on seawater and on ultra pure water is obtained provided that the handling of the samples is the same. The water we used was de-ionised reverse osmosis water (Milli-Q water (Millipore, USA)) with a resistance of $18.2 \mathrm{M} \Omega \mathrm{cm}$ and total organic carbon of less than $10 \times 10^{-9}$ immediately after purification. It was made from Braunschweig tap water. The reference density value was taken from the IAPWS-95 formulation (Wagner and Pruß, 2002). A correction was made for the isotopic composition. This was measured to be $-8.5 \delta \%$ o for ${ }^{18} \mathrm{O}$ and $-59 \delta \%$ for D compared to Vienna Standard
Mean Ocean Water. Thus, the density reference value for this Braunschweig tap water is $999.0996 \mathrm{~kg} / \mathrm{m}^{3}$ at $15^{\circ} \mathrm{C}$.

An uncorrelated uncertainty contribution is given by the reproducibility of the device measurement temperature $\Delta t_{\text {reproducibility }}$ it was measured to be below $3 \mathrm{mK}$. Another uncertainty contribution arises from the deviation of the device measurement temperature $\Delta t_{\text {device }}$ from the absolute temperature. This can be expressed as a calibration uncertainty of the measurement temperature. With our device $\Delta t_{\text {device }}$ was measured to be $0 \mathrm{mK}$ at $15^{\circ} \mathrm{C}$ and $-5 \mathrm{mK}$ at $25^{\circ} \mathrm{C}$. The uncertainty of individual temperature measurements is $\pm 5 \mathrm{mK}$. Typical temperature deviations for other devices of the same type are $20 \mathrm{mK}$. The two temperature deviations act in a different way for seawater and for ultra pure water, as their effect on density is given by multiplying with the thermal expansion coefficient $\gamma$ which is different for seawater and for ultra pure water:

$\rho_{\text {pure water measured }}=$

$\rho_{\text {pure water }}\left(1+\gamma\right.$ pure water measured $\left.\left(\Delta t_{\text {device }}+\Delta t_{\text {reproducibility }}\right)\right)$

$\rho_{\text {seawater measured }}=$

$\rho_{\text {seawater }}\left(1+\gamma_{\text {seawater measured }}\left(\Delta t_{\text {device }}+\Delta t_{\text {reproducibility }}\right)\right)$.

Here, $\rho_{\text {pure water measured }}$ and $\rho_{\text {seawater measured }}$ are the densities indicated by the measuring device, whereas $\rho_{\text {pure water }}$ and $\rho_{\text {seawater denote the real densities. }}$

A third uncorrelated uncertainty contribution is caused by the different handling of the samples concerning its gas content. The ultra pure water is degassed and will remain degassed during the measurement, whereas the seawater is saturated with air. The gas content is determined by the storage temperature of the seawater; during the short time the sample is cooled or heated to the measuring temperature (about $15 \mathrm{~min}$ ) no new equilibration will occur. Thus, the storage temperature affects the density by the gas content. This effect can be reduced by storing the samples at well controlled reproducible conditions. In our measurements we stored the samples at refrigerator temperatures and warmed them up to room temperature over night before measuring. The contribution of this handling to the combined uncertainty (GUM, 2008) is not investigated up to now and, thus, estimated to be rectangular with a halfwidth of $0.5 \mathrm{ppm}$.

\subsection{Ion chromatography}

The mass fractions of chloride, bromide and sulphate of the samples 361, ABB and 213 were determined by means of ion chromatography. For validation purposes the mass fractions of the same anions were measured in a P149 SSW sample. The P149 results for chloride and sulphate were compared to earlier results on sample P149 determined also by ion chromatography but using a different instrumental configuration. 
The ion chromatography system used here consisted of a Metrohm 881 Compact IC pro (Metrohm, Switzerland) with a Metrosep A Supp 5 column. The eluent was $3.2 \mathrm{mmol} / \mathrm{L}$ sodium carbonate plus $1 \mathrm{mmol} / \mathrm{L}$ sodium hydrogen carbonate.

All solutions were prepared gravimetrically using Milli-Q water (Millipore, USA). All seawater samples were diluted prior to injection. The calibration solutions were prepared from certified standard solutions delivered by Fluka (Fluka, Switzerland). The mass fractions as specified by the manufacturer are for:

\section{chloride: $w_{\mathrm{Cl}}=1003 \pm 3 \mathrm{mg} / \mathrm{kg}$}

sulphate: $w_{\mathrm{SO}_{4}}=1006 \pm 8 \mathrm{mg} / \mathrm{kg}$

bromide: $w_{\mathrm{Br}}=1003 \pm 4 \mathrm{mg} / \mathrm{kg}$.

Calibration solutions containing similar mass fractions of anions as the seawater samples were prepared from the standards. Three series of measurements, each using freshly prepared sample dilutions were generated for chloride, sulphate and bromide, respectively. Mean values of the mass fractions are reported from these measurements in Table 6. The relative expanded uncertainties (coverage factor $k=2$ ) are $0.5 \%$ for chloride, $0.8 \%$ for sulphate and $1 \%$ for bromide. The main contributions to the measurement uncertainty are from the mass fractions of the certified standard solutions and from the preparation of the sample and calibration solution, respectively, by dilution.

\section{Results}

\subsection{Parameterisation of Absolute Salinity}

The 438 samples collected in the period 2006-2009 in the Baltic Sea between the Kattegat and the Gulf of Bothnia (Fig. 5) were analysed for Practical Salinity, Sect. 3.2, and density, Sect. 3.4. The related regression line computed from (4) using 436 samples with salinity $S_{\mathrm{R}}>2 \mathrm{~g} \mathrm{~kg}^{-1}$ is

$$
\begin{aligned}
S_{\mathrm{A}}-S_{\mathrm{R}} & =0.00247 \cdot\left(S_{\mathrm{SO}}-S_{\mathrm{R}}\right) \\
& =86.9 \mathrm{mgkg}^{-1} \cdot\left(1-\frac{S_{\mathrm{R}}}{S_{\mathrm{SO}}}\right),
\end{aligned}
$$

as shown in Fig. 8. Here, the standard-ocean salinity is $S_{\mathrm{SO}}=35 u_{\mathrm{PS}}=35.16504 \mathrm{gkg}^{-1}$ (Millero et al., 2008). Comparison of (Eq. 3) with (5) suggests that the density anomaly has decreased by about $40 \%$ during the last 40 years. This result is in contrast to the findings of Dyrssen (1993), and of Kremling and Wilhelm (1997) that the mean calcium concentrations increased significantly by about $4 \%$ between 1966/69 and 1994/95.

The causes of the strong decadal variability are not known; it may be related to technical, agricultural or climatological changes in the drainage region of the Baltic Sea, and/or to the dramatic transition in the inflow regime from the North Sea

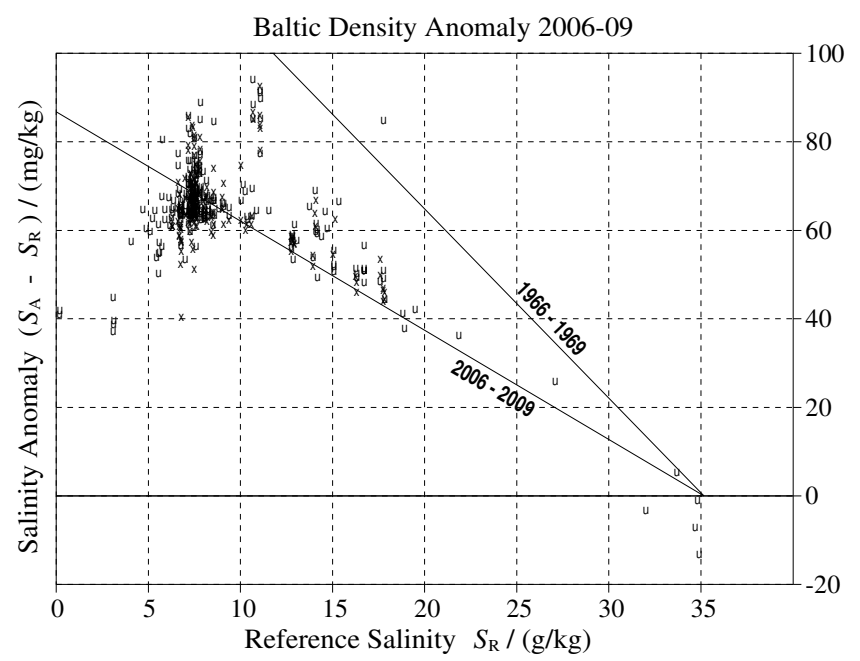

Fig. 8. The results of densitometer measurements in the Baltic Sea during 2006-2009, Fig. 5, converted to Absolute Salinity anomalies using (Eq. 4). Symbol "x": filtered samples, "u": unfiltered samples. 436 samples with salinity $>2 \mathrm{~g} \mathrm{~kg}^{-1}$ were used for the fit (Eq. 3). At vanishing Reference Salinity $S_{\mathrm{R}}$, the limiting anomaly is $S_{\mathrm{A}}^{0}=86.8 \mathrm{mgkg}^{-1}$. There is no significant systematic difference between the fits using the data from filtered or unfiltered samples; the intercept is $87.0 \mathrm{mg} / \mathrm{kg}$ for only the 168 filtered " $\mathrm{x}$ " samples, and $86.6 \mathrm{mg} / \mathrm{kg}$ for only the 270 unfiltered "u" samples. The line marked 1966-1969 is the regression line (5) with regard to the data from 1966-69 of Millero and Kremling (1976), Fig. 1.

that occurred in the 1980s (Matthäus et al., 2008), and the related consequences for the marine chemistry in the deep water (Nausch et al., 2008).

For three selected Baltic Sea water samples taken in November 2008 from the surface water at the stations 361 (Kiel Bight), ABB (Arkona Basin) and 213 (Bornholm Deep), Fig. 5, the analysis was repeated with state-of-theart measurements of the absolute conductivity, Sect. 3.3, and of density, Sect. 3.5.

The results, Table 3, of the comparison between measurements of density and conductivity at PTB and IOW can be pairwise combined to compute the salinity anomaly as a function of the Reference Salinity, Fig. 9. The four combinations are very close to each other and confirm the regression (Eq. 3) based on the full set of IOW measurements.

In Fig. 10, the results from the density measurements of PTB and IOW, Table 3, are combined with chlorinity values of the samples computed from the ion chromatography, Table 6, for comparison with Fig. 3. Fig. 10 shows a riverine salt input of $130 \mathrm{mg} / \mathrm{kg}$, which is a reduced value compared to the data from 1966-1969 but enhanced compared to the value of $30 \mathrm{mg} / \mathrm{kg}$ from 1901, and to $79 \mathrm{mg} / \mathrm{kg}$ reported by Ohlson and Anderson (1990). Our recent value has high uncertainty due to the small number of samples used for its computation. 
Table 3. Independent PTB measurements of conductivity and density of Baltic surface water at the selected stations 361 , ABB and 213 , Fig. 5, compared with the IOW data for density and Practical Salinity. All values are given at $15^{\circ} \mathrm{C}$ and atmospheric pressure, except IOW density which was measured at $20^{\circ} \mathrm{C}$. Values for $S_{\mathrm{A}}$ were computed from the related density by means of (3). Note that the effect of temperature on density is automatically removed when calculating the "density salinity", which is reported as $S_{\mathrm{A}}$. Related expanded uncertainties (coverage factor 2) are given below the values

\begin{tabular}{|c|c|c|c|c|c|c|c|}
\hline Sample & $\begin{array}{l}\mathrm{PTB} \\
C\left(15^{\circ} \mathrm{C}\right) \\
\mathrm{S} \mathrm{m}^{-1}\end{array}$ & $\begin{array}{l}\text { PTB } \\
S_{\mathrm{P}}\end{array}$ & $\begin{array}{l}\text { IOW } \\
S_{\mathrm{P}}\end{array}$ & $\begin{array}{l}\mathrm{PTB} \\
\rho\left(15^{\circ} \mathrm{C}\right) \\
\mathrm{kg} \mathrm{m}^{-3}\end{array}$ & $\begin{array}{l}\text { PTB } \\
S_{\mathrm{A}} \\
\mathrm{g} \mathrm{kg}^{-1}\end{array}$ & $\begin{array}{l}\text { IOW } \\
\rho\left(20^{\circ} \mathrm{C}\right) \\
\mathrm{kg} \mathrm{m}^{-3}\end{array}$ & $\begin{array}{l}\text { IOW } \\
S_{\mathrm{A}} \\
\mathrm{g} \mathrm{kg}^{-1}\end{array}$ \\
\hline \multirow[t]{2}{*}{361} & 2.29564 & 17.5487 & 17.5438 & 1012.5989 & 17.6746 & 1011.5384 & 17.6732 \\
\hline & 0.00136 & 0.0116 & 0.0020 & 0.0014 & 0.0018 & 0.0130 & 0.0192 \\
\hline \multirow[t]{2}{*}{$\mathrm{ABB}$} & 1.24454 & 9.0190 & 9.0166 & 1006.0781 & 9.1205 & 1005.0975 & 9.1223 \\
\hline & 0.00050 & 0.0046 & 0.0010 & 0.0014 & 0.0019 & 0.0130 & 0.0182 \\
\hline \multirow[t]{2}{*}{213} & 1.06730 & 7.6403 & 7.6409 & 1005.0259 & 7.7402 & 1004.0577 & 7.7415 \\
\hline & 0.00030 & 0.0034 & 0.0009 & 0.0021 & 0.0028 & 0.0130 & 0.0181 \\
\hline
\end{tabular}

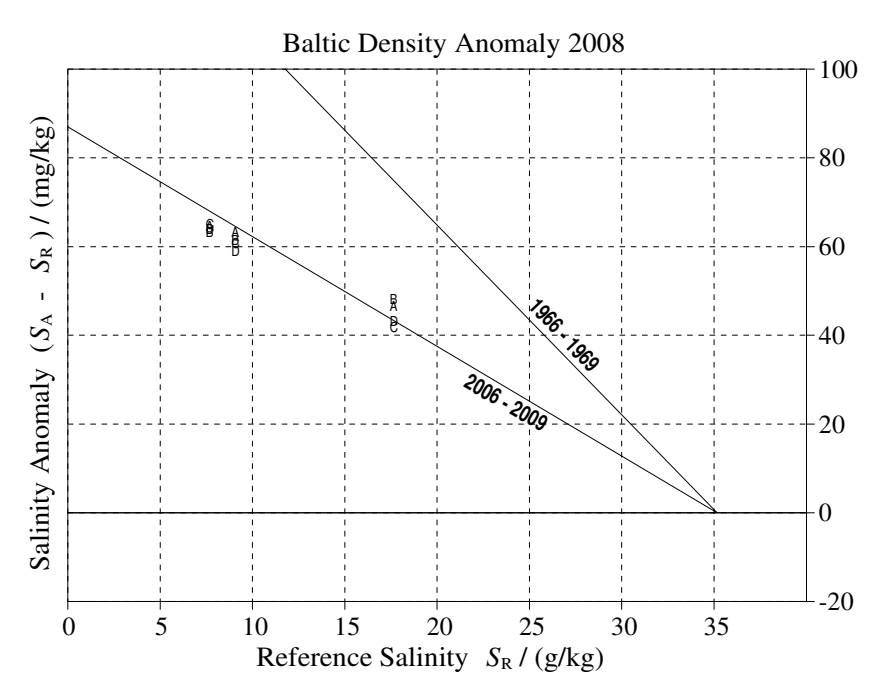

Fig. 9. Results of PTB-IOW comparison measurements of the salinity anomaly as a function of the Reference Salinity of the Baltic Sea samples 361, ABB and 213, Table 3. Symbols "A", "B" in the diagram: $S_{\mathrm{R}}$ from IOW, "A", "C": $S_{\mathrm{A}}$ from IOW, "C", "D": $S_{\mathrm{R}}$ from PTB, and "B", "D": $S_{\mathrm{A}}$ from PTB. The line marked 2006-2009 is the regression line (Eq. 3) with regard to the data 2006-9 of this paper, Fig. 8. The line marked 1966-1969 is the regression line (5) with regard to the data 1966-69 of Millero and Kremling (1976), Fig. 1.

For Standard Seawater, Reference Salinity (2) equals chlorinity salinity (6), while for the Baltic Sea their difference indicates the electrolytic conductivity of the riverine water, Fig. 4 and the discussion following (10). The similar graph to 4 , computed from the samples $361, \mathrm{ABB}$ and 213 collected in 2008, is shown in Fig. 11. The strong scatter of the few available data points prevents any definite conclusions on a possible change of the river water composition since 1969.

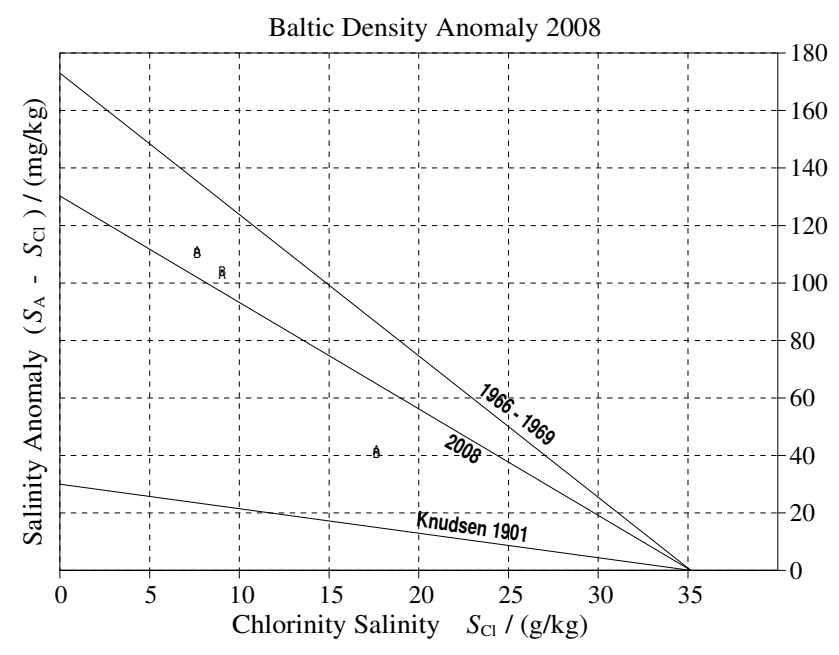

Fig. 10. Results of PTB-IOW comparison measurements of the salinity anomaly, Table 3 , as a function of the chlorinity of the Baltic Sea samples 361, ABB and 213, Table 6. Symbols A: $S_{\mathrm{A}}$ from IOW, B: $S_{\mathrm{A}}$ from PTB. The regression line "2008" with respect to these data has an intercept of $130 \mathrm{mg} / \mathrm{kg}$ at $S_{C l}=0$. The line marked "1966-1969" is the regression line (8) associated with the data from 1966-69 of Millero and Kremling (1976), Fig. 3. The "Knudsen 1901" (Eq. 9) was derived by Knudsen (1901) from the measurements of Sørensen (Forch et al., 1902), Table 3, Fig. 3.

\subsection{Density comparison measurements}

The density measurements carried out at the PTB, Sect. 3.4, on Baltic seawater samples collected in November 2008 at the station 213, ABB and 361, Fig. 5, served two different purposes, i) an independent confirmation of the density results obtained at the IOW, Sect. 3.2, and ii) a study of the uncertainty of seawater density measurements intended to be used as an SI-traceable substitute for salinity measurements that are traceable only to the IAPSO Standard Seawater artefact which is not a part of the SI system. 


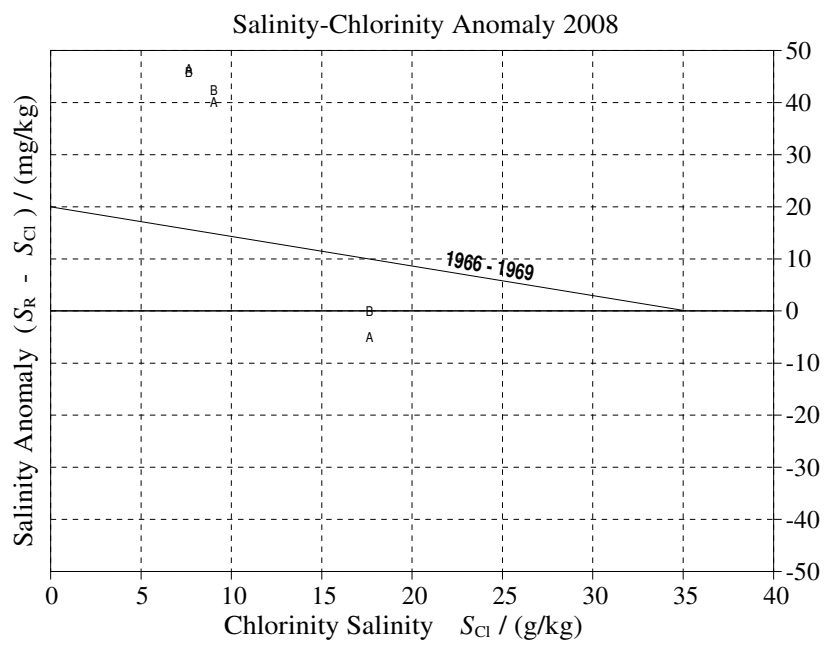

Fig. 11. Deviation between Reference Salinity (2), $S_{\mathrm{R}}$, from Table 3 , and chlorinity salinity (6), $S_{C l}$, from Table 6 , of the Baltic Sea samples 361, ABB and 213, compared with the regression line "1966-1969" with respect to Kremling's data collected between 1966 and 1969, Fig. 4. The deviation from the abscissa quantifies the conductivity of the riverine water. Symbols A with Practical Salinity from the IOW, B from the PTB.

The results of the PTB density measurements are reported in detail in Tables 4, 5 and Figs. 12-15. Expanded uncertainties for seawater densities are estimated to be in the range of $1-2 \mathrm{mg} / \mathrm{m}^{3}$, the standard deviation of pure-water measurements is even below $1 \mathrm{mg} / \mathrm{m}^{3}$.

The agreement of the PTB results with IOW data is excellent, as seen from the Absolute Salinity results shown in Table 3 and Figs. 9-10. The lowering of the Baltic salinity anomaly in 2006-9 compared to 1966-69 derived from IOW data is confirmed by the PTB determinations.

The typical uncertainties displayed in Figs. 12-14 for Baltic Seawater apply similarly to Standard Seawater; Fig. 15; the measurement method is not modified for brackish salinities. The uncertainties of salinities $S_{\mathrm{A}}$ computed from the PTB density measurements, Table 3, are comparable to those of the Practical Salinity measured at IOW with conventional conductivity methods. Thus, the results presented here support the idea of measuring salinity by means of SI-traceable density.

Another important aspect of the substitution method used here is the automatic consistency with IAPWS-95 densities of pure water. This permits the computation of the saline part of the specific volume of seawater (IAPWS, 2008) from measured seawater densities without additional loss of accuracy.

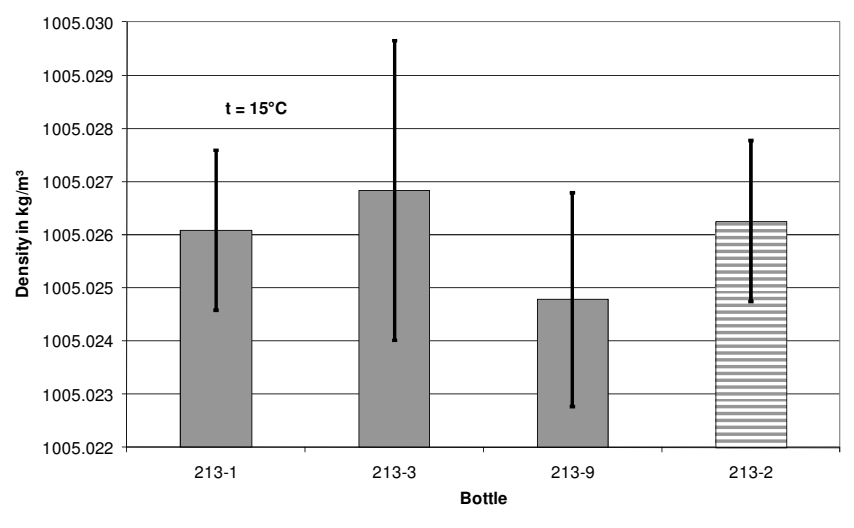

Fig. 12. Densities and uncertainties of the different batches, Table 4, of surface water from the Baltic Sea station 213, Fig. 5, measured at the PTB.

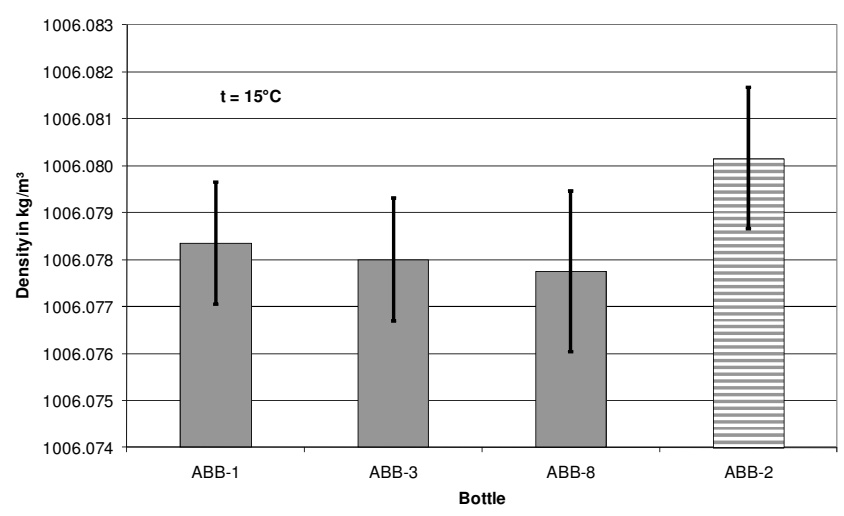

Fig. 13. Densities and uncertainties of the different batches, Table 4 , of surface water from the Baltic Sea station ABB, Fig. 5, measured at the PTB

\subsection{Conductivity comparison measurements}

Figure 16 shows the differences between Practical Salinity measured at the IOW with a salinometer $\left(S_{\mathrm{P}}^{\text {sal }}\right)$, Sect. 3.2, and Practical Salinity calculated from absolute conductivity measurements $\left(S_{\mathrm{P}}^{\text {abs }}\right)$, Sect. 3.3. Zero in Fig. 16 can be taken as a representative for $S_{\mathrm{P}}^{\mathrm{abs}}$, the dots then mark the deviation of $S_{\mathrm{P}}^{\text {sal }}$ with respect to $S_{\mathrm{P}}^{\mathrm{abs}}$. The error bars indicate the expanded (coverage factor 2) uncertainties. Bars with a cross bar are those of $S_{\mathrm{P}}^{\text {sal }}$ and without cross bars those of $S_{\mathrm{P}}^{\text {abs }}$. They indicate a $95 \%$ degree of confidence for the results. Only the statistical fluctuation of the internally measured conductance enters into the uncertainty of $S_{\mathrm{P}}^{\mathrm{sal}}$, since systematic uncertainties are assumed to cancel out by the SSW calibration procedure. In an absolute conductivity measurement the absolute conductance value of seawater in the measuring cell must be determined. Its uncertainty therefore enters into the uncertainties of $C_{\mathrm{S}}$ and $C_{\mathrm{SSW}}$ in (Eq. 2). This results in a larger uncertainty of $S_{\mathrm{P}}^{\text {abs }}$ as can be seen in Fig. 16. 
Table 4. Results of the high-accuracy measurements of seawater density carried out at the PTB. Absolute Salinity is computed from the density by means of the Gibbs function (3). Given is the expanded uncertainty of the density at $15^{\circ} \mathrm{C}$ (coverage factor 2 ).

\begin{tabular}{lllllll}
\hline sample & $\begin{array}{l}\text { date of } \\
\text { filling }\end{array}$ & $\begin{array}{l}\text { date of } \\
\text { measurement }\end{array}$ & storage & $\begin{array}{l}\text { density } \\
\text { at } 15^{\circ} \mathrm{C}\end{array}$ & $\begin{array}{l}\text { total } \\
\text { uncertainty } \\
U(\rho)(k=2)\end{array}$ & $\begin{array}{l}\text { Absolute } \\
\text { Salinity } S_{\mathrm{A}}\end{array}$ \\
& & & & & \\
$\mathrm{kg} / \mathrm{m}^{3}$ & $\mathrm{~kg} / \mathrm{m}^{3}$ & & $\mathrm{~kg}$ \\
\hline $213-1$ & $2008-12-18$ & $2009-02-04$ & refrigerator & 1005.0261 & $1.5 \mathrm{E}-03$ & 7.7405 \\
$213-3$ & $2008-12-18$ & $2009-03-11$ & refrigerator & 1005.0268 & $2.8 \mathrm{E}-03$ & 7.7414 \\
$213-9$ & $2008-12-18$ & $2009-03-27$ & refrigerator & 1005.0248 & $2.0 \mathrm{E}-03$ & 7.7388 \\
$213-2$ & $2008-12-18$ & $2009-02-03$ & room temp. & 1005.0263 & $1.5 \mathrm{E}-03$ & 7.7408 \\
ABB-1 & $2008-12-17$ & $2009-02-05$ & refrigerator & 1006.0784 & $1.3 \mathrm{E}-03$ & 9.1209 \\
ABB-3 & $2008-12-17$ & $2009-03-10$ & refrigerator & 1006.0780 & $1.3 \mathrm{E}-03$ & 9.1204 \\
ABB-8 & $2008-12-17$ & $2009-03-26$ & refrigerator & 1006.0778 & $1.7 \mathrm{E}-03$ & 9.1201 \\
ABB-2 & $2008-12-17$ & $2009-01-29$ & room temp. & 1006.0802 & $1.5 \mathrm{E}-03$ & 9.1233 \\
$361-1$ & $2008-12-16$ & $2009-03-09$ & refrigerator & 1012.5983 & $1.4 \mathrm{E}-03$ & 17.6738 \\
$361-9$ & $2008-12-16$ & $2009-03-25$ & refrigerator & 1012.5995 & $1.4 \mathrm{E}-03$ & 17.6753 \\
$361-2$ & $2008-12-16$ & $2009-02-02$ & room temp. & 1012.5971 & $1.9 \mathrm{E}-03$ & 17.6722 \\
& & & & & & 35.1538 \\
P151-1 & & $2009-04-06$ & room temp. & 1025.96745 & $2.2 \mathrm{E}-03$ & 35.1525 \\
P151-2 & & $2009-04-07$ & room temp. & 1025.96641 & $1.3 \mathrm{E}-03$ & 35.1535 \\
P151-3 & & $2009-04-08$ & room temp. & 1025.96722 & $1.9 \mathrm{E}-03$ & 35.1590 \\
P151-4 & & $2009-04-09$ & room temp. & 1025.97145 & $1.5 \mathrm{E}-03$ & \\
\hline
\end{tabular}

Table 5. Experimental standard deviations of the mean (st. dev.) and numbers of measurements of the high-accuracy measurements of density carried out at the PTB with seawater and with pure water.

\begin{tabular}{|c|c|c|c|c|c|}
\hline sample & $\begin{array}{l}\text { seawater } \\
\text { st. dev. } \\
u(\rho)(k=1) \\
\mathrm{kg} / \mathrm{m}^{3}\end{array}$ & $\begin{array}{l}\text { seawater } \\
\text { number of } \\
\text { measurements }\end{array}$ & $\begin{array}{l}\text { seawater } \\
\text { therm. expansion } \\
\text { coefficient at } 15^{\circ} \mathrm{C} \\
K^{-1}\end{array}$ & $\begin{array}{l}\text { pure water } \\
\text { st. dev. } \\
U(\rho)(k=2) \\
\mathrm{kg} / \mathrm{m}^{3}\end{array}$ & $\begin{array}{l}\text { pure water } \\
\text { number of } \\
\text { measurements }\end{array}$ \\
\hline $213-1$ & $3.8 \mathrm{E}-04$ & 16 & 0.00016628 & $3.9 \mathrm{E}-04$ & 20 \\
\hline $213-3$ & $1.3 \mathrm{E}-03$ & 20 & 0.00016628 & $3.1 \mathrm{E}-04$ & 24 \\
\hline $213-9$ & 7.0E-04 & 20 & 0.00016628 & $4.8 \mathrm{E}-04$ & 26 \\
\hline $213-2$ & $4.5 \mathrm{E}-04$ & 12 & 0.00016628 & $3.2 \mathrm{E}-04$ & 16 \\
\hline ABB-1 & $2.5 \mathrm{E}-04$ & 16 & 0.00016893 & $3.8 \mathrm{E}-04$ & 18 \\
\hline ABB-3 & $3.4 \mathrm{E}-04$ & 18 & 0.00016893 & $2.4 \mathrm{E}-04$ & 22 \\
\hline ABB-8 & $5.0 \mathrm{E}-04$ & 14 & 0.00016893 & 4.5E-04 & 18 \\
\hline ABB-2 & $3.1 \mathrm{E}-04$ & 20 & 0.00016893 & $4.6 \mathrm{E}-04$ & 22 \\
\hline $361-1$ & $4.3 \mathrm{E}-04$ & 18 & 0.0001847 & $2.2 \mathrm{E}-04$ & 22 \\
\hline $361-9$ & $3.1 \mathrm{E}-04$ & 18 & 0.0001847 & 3.0E-04 & 22 \\
\hline $361-2$ & $7.5 \mathrm{E}-04$ & 20 & 0.0001847 & $2.9 \mathrm{E}-04$ & 20 \\
\hline P151-1 & $7.5 \mathrm{E}-04$ & 18 & 0.00016628 & 4.7E-04 & 22 \\
\hline P151-2 & $4.8 \mathrm{E}-04$ & 18 & 0.00016628 & $1.7 \mathrm{E}-04$ & 22 \\
\hline P151-3 & $5.5 \mathrm{E}-04$ & 18 & 0.00016893 & $3.8 \mathrm{E}-04$ & 22 \\
\hline P151-4 & $2.6 \mathrm{E}-04$ & 18 & 0.00016893 & $3.0 \mathrm{E}-04$ & 22 \\
\hline
\end{tabular}

Figure 16a compares results where $R_{15}$ of the absolute measurement is scaled with the measured conductivity value of SSW/P-series, having a nominal Practical Salinity around 35 . Here all salinometer and absolute measurements fit very well within the uncertainty limits. Figure $16 \mathrm{~b}$ compares re- sults where $R_{15}$ of the absolute measurement is scaled with the measured conductivity value of SSW/L10-series, which is SSW diluted to a nominal Practical Salinity around 10 . Although the uncertainty ranges of the salinometer and the absolute measurement results do barely touch this must be 


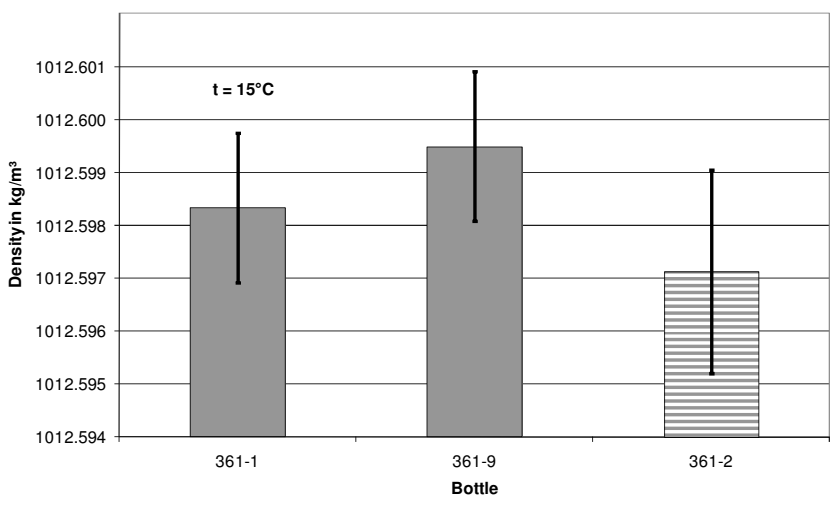

Fig. 14. Densities and uncertainties of the different batches, Table 4, of surface water from the Baltic Sea station 361, Fig. 5, measured at the PTB.

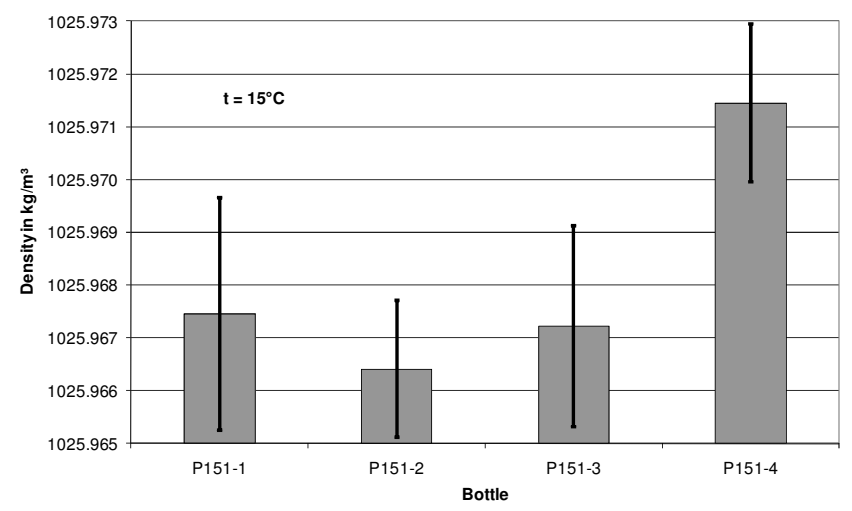

Fig. 15. Densities and uncertainties of the different batches of IAPSO Standard Seawater, measured at the PTB. The outlier of bottle P151-4 is not attributed to a measurement effect but should be interpreted as an indication for evaporation of water caused by an imperfect sealing of the bottle.

assessed as a significant deviation. This is an unexpected observation; we may only speculate here about the reasons. Since PSS-78 is based on Practical Salinity measurements of SSW at different salt concentrations, scaling with SSW/Pseries or L10-series should lead to the same result. The deviation may be an indicator that today's internal scaling of the measuring device is different to the devices taken to establish PSS-78. Alternatively, e.g., the physical chemical properties of SSW may have slightly changed such that PSS-78 cannot be reproduced anymore over the complete scale. Of course, such a far-reaching conclusion can certainly not be drawn from such a small set of measurements with lacking statistical significance. Consequently, further investigation is currently ongoing. But based on the present results in the Baltic Sea measurement range one has to expect an additional uncertainty contribution to Practical Salinity in the order of the deviation of about $0.06 \%$ to $0.07 \%$. At least the results demonstrate the necessity of an independent and stable reference for Practical Salinity measurements like the SI.
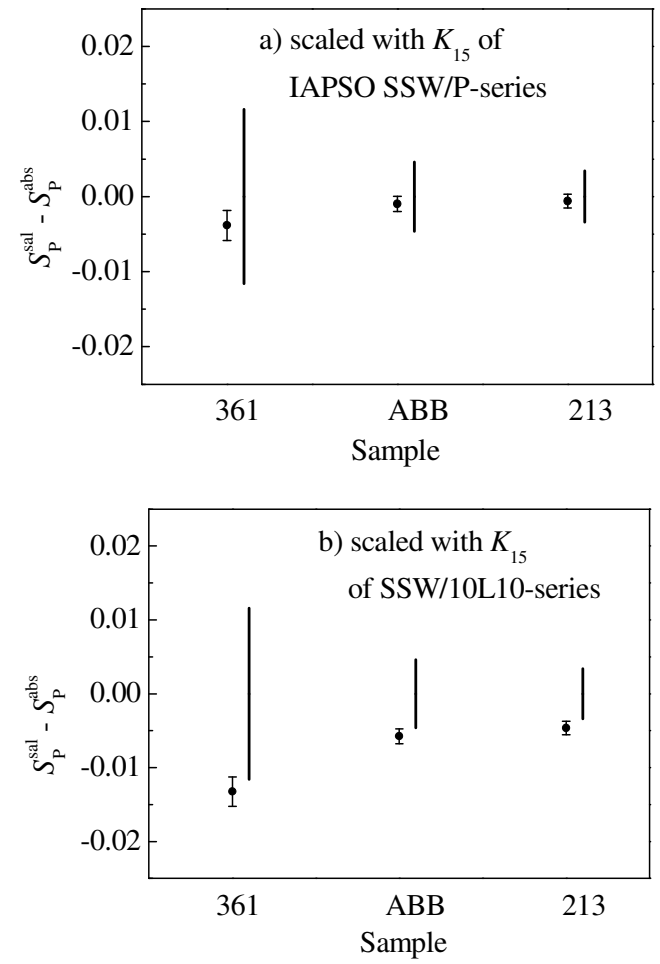

Fig. 16. Deviation of Practical Salinity results $S_{\mathrm{P}}^{\mathrm{sal}}$ measured with a salinometer from those calculated from absolute conductivity measurements $S_{\mathrm{P}}^{\mathrm{abs}}$. Error bars without cross bars are related to zero (deviation) and indicate the expanded uncertainty of $S_{\mathrm{P}}^{\text {abs }}$, while the error bars with cross bars indicate the expanded uncertainty of $S_{\mathrm{P}}^{\mathrm{sal}}$. (a) Absolute conductivity results scaled according to (Eq. 2) using SSW/P-series, (b) using SSW/10L10 series.

\subsection{Chemical composition}

Table 6 summarizes the results of the ion chromatography measurements, Sect. 3.6, together with the expanded uncertainties $^{4}$ (coverage factor 2, GUM 2008). The mass fractions of the anions chloride, bromide and sulphate were determined in the samples $361, \mathrm{ABB}$ and 213 and in a sample of P149 SSW. In columns 2 and 3 of Table 8 the mass fractions of sulphate to chloride and bromide to chloride are given. Figs. 18 and 19 show the results graphically. In Fig. 17 the mass fractions of sulphate determined in two samples of P149 SSW are compared. One sample P149 was measured at the same time as the Baltic Sea samples the other was measured one year before using a different instrumental configuration (Metrohm 850 professional IC, Metrosep A Supp 4/5 Guard column, Metrohm, Switzerland) and done

\footnotetext{
${ }^{4}$ The expanded uncertainty $U$ defines an interval about the result of the measurement. $U$ is calculated from a combined standard uncertainty $u_{\mathrm{c}}$ and a coverage factor $k: U=k u_{\mathrm{c}}$. A coverage factor $k=2$, as applied in the publication, corresponds for a normal distribution to a coverage probability of approximately $95 \%$.
} 


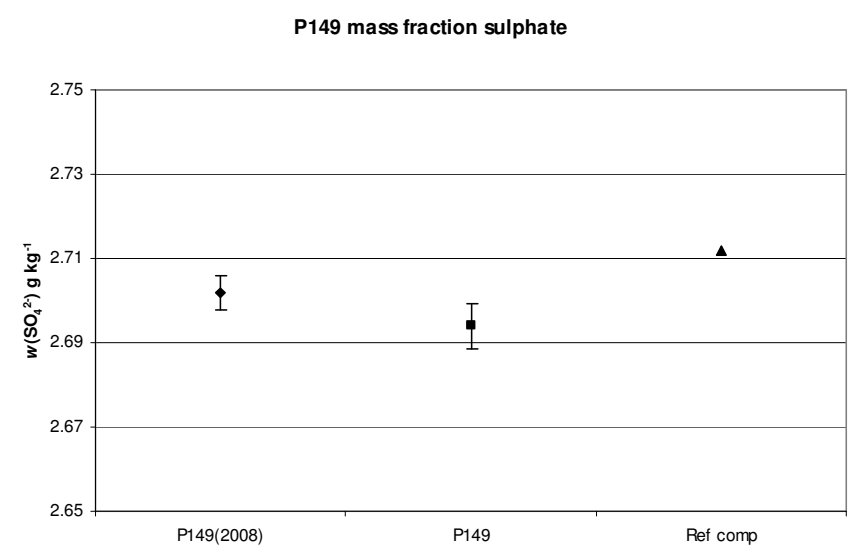

Fig. 17. Mass fraction of sulphate measured in SSW P149 in parallel with Baltic Sea samples and in 2008 at PTB compared to the Reference Composition (Millero et al., 2008).

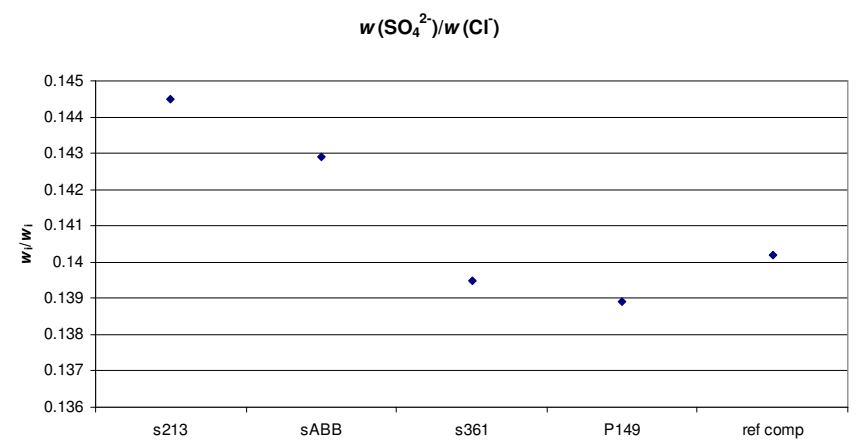

Fig. 18. Mass fraction of sulphate to chloride for the Baltic Sea samples. SSW P149 and to the Reference Composition (Millero et al., 2008).

by a different operator. The results shown in Table 7 agree well within the stated uncertainty. For sulphate both values are slightly below the Reference Composition (Millero et al., 2008) as can be seen from Fig. 17. The mass fractions of bromide to chloride and sulphate to chloride of the Baltic Sea samples were compared to the ratio of anions as obtained for P149 and as given for the Reference Composition. The results are summarized in Table 8 and shown in Figs. 18 and 19. Results for calcium could not be obtained.

In addition to $\mathrm{CaCO}_{3}$, the Baltic Sea exhibits a weaker anomaly in $\mathrm{MgSO}_{4}$ (Rohde, 1966; Kremling, 1969; Nehring, 1980; Nessim and Schlungbaum, 1980), Table 2. Apparently the ratios $w\left(\mathrm{SO}_{4}^{2-}\right) / w\left(\mathrm{Cl}^{-}\right)$given in Table 8 show a related systematic trend proportional to the chlorinity. The sulphate fraction of Standard Seawater can be computed from the Reference Composition (Millero et al., 2008), Table 2, and subtracted from the measured sulphate concentration, $\mathrm{SO}_{4}^{\text {meas }}$, to provide an estimate of the mean riverine sulphate input, $\mathrm{SO}_{4}^{\text {river }}$, as

$\mathrm{SO}_{4}^{\text {river }}=\mathrm{SO}_{4}^{\text {meas }}-0.14 \mathrm{Cl}$

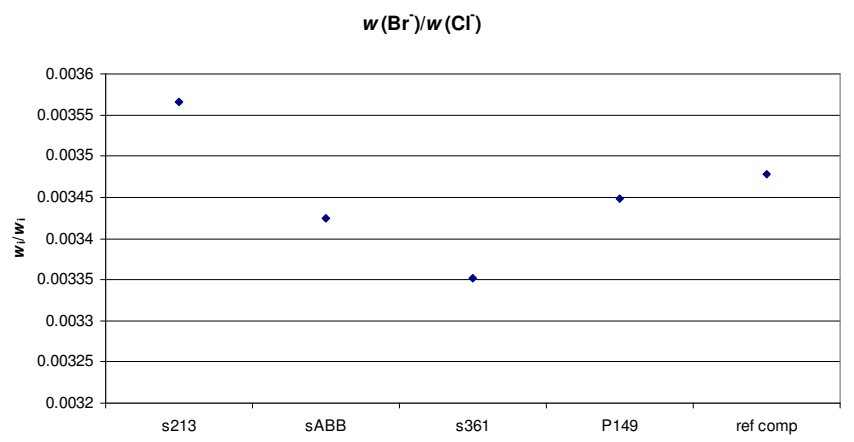

Fig. 19. Mass fraction of bromide to chloride for the Baltic Sea samples, SSW P149 and the Reference Composition (Millero et al., 2008).

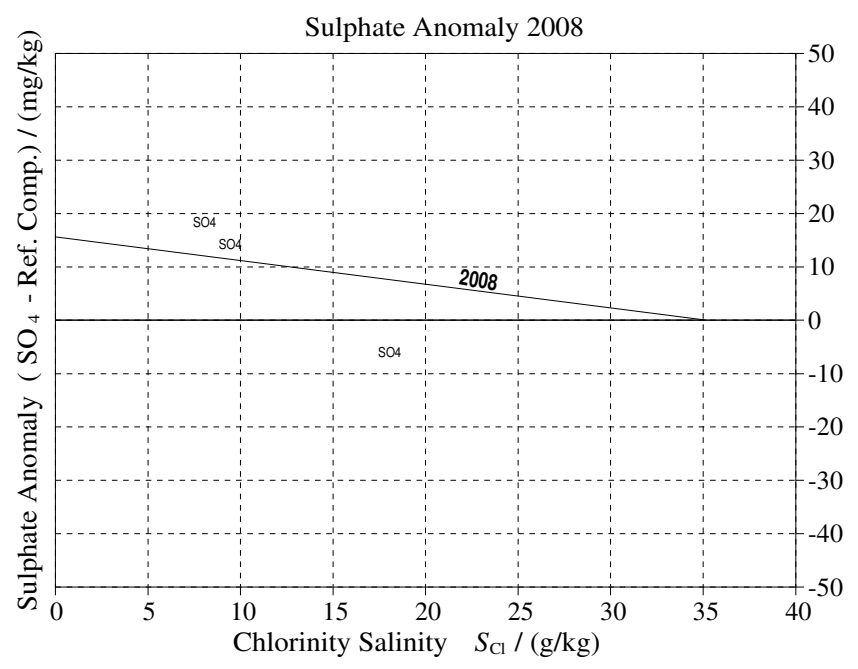

Fig. 20. Sulphate anomaly with respect to the Reference Composition computed from (Eq. 4) with measured values, Table 6, at the Baltic Sea stations 213, ABB and 361 in November 2008, symbols "SO4". The regression line "2008" with respect to these data suggests a riverine discharge of order $16 \mathrm{mg} / \mathrm{kg}$ of $\mathrm{SO}_{4}$. The uncertainty in this estimate is large due to the few available samples.

The result for the data given in Table 6 computed from (Eq. 4) is displayed in Fig. 20. The regression results in an intercept at $C l=0$ of about $16 \mathrm{mg} / \mathrm{kg}$ of $\mathrm{SO}_{4}$ discharged from the rivers; due to the small number of samples a high uncertainty of this value must be assumed.

\subsection{Contribution of $\mathrm{CaCO}_{3}$ dissolution to the salinity anomaly}

The dissolution of $\mathrm{CaCO}_{3}$ in river water adds $\mathrm{Ca}$ and total $\mathrm{CO}_{2}\left(C_{\mathrm{T}}=\mathrm{CO}_{2}+\mathrm{H}_{2} \mathrm{CO}_{3}+\mathrm{HCO}_{3}^{-}+\mathrm{CO}_{3}^{2-}\right)$ to the Baltic Sea and constitutes the major contribution to the salinity anomaly in the Baltic Sea. To quantify this effect, a subset of the samples from stations 2, 113, 213, 256, 271, and 284 (Fig. 5) collected between 2006 and 2008 
Table 6. Mass fraction of chloride, sulphate and bromide for Baltic Sea samples 213, ABB and 361 together with the expanded measurement uncertainty (coverage factor 2). Chlorinity $\mathrm{Cl}$ is computed from the formula (Millero et al., 2008),

$C l=0.3285234 A_{\mathrm{Ag}}\left[w(\mathrm{Cl}) / A_{\mathrm{Cl}}+w(\mathrm{Br}) / A_{\mathrm{Br}}\right]$, and the chlorinity salinity $S_{C l}$ is computed from (Eq. 6).

\begin{tabular}{lllllll}
\hline Sample & 213 & & $\mathrm{ABB}$ & 361 & \\
\hline $\begin{array}{l}\text { Seawater } \\
\text { component } i\end{array}$ & $\begin{array}{l}w(i) \\
\mathrm{g} \mathrm{kg}^{-1}\end{array}$ & $\begin{array}{l}U(w(i)) \\
\mathrm{g} \mathrm{kg}^{-1}\end{array}$ & $\begin{array}{l}w(i) \\
\mathrm{g} \mathrm{kg}^{-1}\end{array}$ & $\begin{array}{l}U(w(i)) \\
\mathrm{g} \mathrm{kg}^{-1}\end{array}$ & $\begin{array}{l}w(i) \\
\mathrm{g} \mathrm{kg}^{-1}\end{array}$ & $\begin{array}{l}U(w(i)) \\
\mathrm{g} \mathrm{kg}^{-1}\end{array}$ \\
\hline $\mathrm{Cl}^{-}$ & 4.199 & 0.020 & 4.964 & 0.025 & 9.704 & 0.050 \\
$\mathrm{SO}_{4}^{2-}$ & 0.607 & 0.0050 & 0.710 & 0.0057 & 1.354 & 0.011 \\
$\mathrm{Br}^{-}$ & 0.015 & 0.0002 & 0.017 & 0.0002 & 0.033 & 0.0003 \\
$C l$ & 4.204 & & 4.969 & & 9.714 & \\
$S_{C l}$ & 7.630 & & 9.020 & & 17.632 & \\
\hline
\end{tabular}

Table 7. Mass fractions of chloride and sulphate measured in SSW P149 in parallel with Baltic Sea samples and in 2008 at PTB, compared to the Reference Composition (Millero et al., 2008).

\begin{tabular}{|c|c|c|c|c|c|c|}
\hline \multirow{2}{*}{$\begin{array}{l}\text { Sample } \\
\begin{array}{l}\text { Seawater } \\
\text { component } i\end{array}\end{array}$} & \multicolumn{2}{|c|}{ P149 this paper } & \multicolumn{2}{|c|}{ P149 PTB in 2008} & \multicolumn{2}{|c|}{$\begin{array}{l}\text { Reference Composition } \\
\text { Millero et al. (2008) }\end{array}$} \\
\hline & $\begin{array}{l}w(i) \\
\mathrm{g} \mathrm{kg}^{-1}\end{array}$ & $\begin{array}{l}U(w(i)) \\
\mathrm{g} \mathrm{kg}^{-1}\end{array}$ & $\begin{array}{l}w(i) \\
\mathrm{g} \mathrm{kg}^{-1}\end{array}$ & $\begin{array}{l}U(w(i)) \\
\mathrm{g} \mathrm{kg}^{-1}\end{array}$ & $\begin{array}{l}w(i) \\
\mathrm{g} \mathrm{kg}^{-1}\end{array}$ & $\begin{array}{l}U(w(i)) \\
\mathrm{g} \mathrm{kg}^{-1}\end{array}$ \\
\hline $\mathrm{Cl}^{-}$ & 19.39 & 0.04 & 19.34 & 0.03 & 19.35271 & \\
\hline $\mathrm{SO}_{4}^{2-}$ & 2.694 & 0.006 & 2.702 & 0.004 & 2.71235 & \\
\hline
\end{tabular}

Table 8. Mass fraction of sulphate to chloride and bromide to chloride for the Baltic Sea samples, the standard seawater sample compared to SSW P149 and to the Reference Composition (Millero et al., 2008).

\begin{tabular}{lcc}
\hline Sample & $w\left(\mathrm{SO}_{4}^{2-}\right) / w\left(\mathrm{Cl}^{-}\right)$ & $w\left(\mathrm{Br}^{-}\right) / w\left(\mathrm{Cl}^{-}\right)$ \\
\hline 213 & 0.1445 & 0.003566 \\
ABB & 0.1429 & 0.003425 \\
361 & 0.1395 & 0.003351 \\
P149 & 0.1389 & 0.003448 \\
Ref. Comp. & 0.1390 & 0.003480 \\
\hline
\end{tabular}

were analyzed for both $C_{\mathrm{T}}(n=64)$ and total alkalinity, $A_{\mathrm{T}}$ $(n=29)$. The chemical analyses for $C_{\mathrm{T}}$ and $A_{\mathrm{T}}$ were performed by coulometry and closed-cell titration, respectively, according to the standard operation procedures described by Dickson et al. (2007). The $A_{\mathrm{T}}$ were plotted as a function of Practical Salinity $S_{\mathrm{P}}$ and a regression line was calculated which was fixed to $A_{\mathrm{T}}=2350 \mu \mathrm{mol} \mathrm{kg}{ }^{-1}$ at $S_{\mathrm{P}}=35$ (Fig. 21). This value corresponds to the ocean endmember of the $A_{\mathrm{T}} / S_{\mathrm{P}}$ mixing diagram and was estimated by extrapolation of $A_{\mathrm{T}}$ measurements in the Belt Sea/Kattegat area (B. Schneider, unpublished data) to $S_{\mathrm{P}}=35$. The scatter of the data around the regression line is considerable and can be explained by the extreme differences in $A_{\mathrm{T}}$ in river wa- ter entering the Baltic Sea. The $A_{\mathrm{T}}$ in Scandinavian rivers amounts to a few hundred $\mu \mathrm{mol} \mathrm{kg}{ }^{-1}$, whereas river water originating from continental Europe have alkalinities larger than $3000 \mu \mathrm{mol} \mathrm{kg}^{-1}$ (Hjalmarsson et al., 2008). Hence, extrapolation of the $A_{\mathrm{T}}$ /salinity regression line to $S_{\mathrm{P}}=0$ yields a mean river water value, ${ }^{\circ} A_{\mathrm{T}}$, that is weighted with the contribution of river water from different source areas. As a consequence, the $A_{\mathrm{T}}$ at a given salinity depends on the horizontal mixing pattern that may vary in space and time, and a well-defined $A_{\mathrm{T}} /$ salinity relationship for the Baltic Sea does not exist. The mean ${ }^{\circ} A_{\mathrm{T}}$ obtained from our limited set of samples was $1470 \mu \mathrm{mol} \mathrm{kg}^{-1}$. Attributing ${ }^{\circ} A_{\mathrm{T}}$ entirely to the dissolution of $\mathrm{CaCO}_{3}$ yields a $\mathrm{Ca}$ concentration in river water of $735 \mu \mathrm{mol} \mathrm{kg}-1$ corresponding to $29 \mathrm{mg} \mathrm{kg}^{-1}$. Maximum and minimum ${ }^{\circ} A_{\mathrm{T}}$ were estimated by calculating upper and lower limit mixing lines which enclosed all $A_{\mathrm{T}}$ data. The ${ }^{\circ} A_{\mathrm{T}}$ ranged from $1339 \mu \mathrm{mol} \mathrm{kg}{ }^{-1}$ to $1585 \mu \mathrm{mol} \mathrm{kg}{ }^{-1}$ and is equivalent to $\mathrm{Ca}$ concentrations between $27 \mathrm{mg} \mathrm{kg}^{-1}$ and $32 \mathrm{mg} \mathrm{kg}^{-1}$. This range is consistent with the river water $\mathrm{Ca}$ concentration $\left(28 \mathrm{mg} \mathrm{kg}^{-1}\right)$ obtained by extrapolation of $\mathrm{Ca}$ measurements at chlorinities higher than 4.5 (Kremling and Wilhelm, 1997).

$\mathrm{CO}_{3}^{2-}$ ions released during the dissolution of $\mathrm{CaCO}_{3}$ react with $\mathrm{CO}_{2}$ and form $\mathrm{HCO}_{3}^{-}$ions according to the thermodynamic equilibrium conditions of the marine $\mathrm{CO}_{2}$ system. Therefore, the total $\mathrm{CO}_{2}$ concentrations in river water are controlled by both the alkalinity and the $\mathrm{CO}_{2}$ partial 


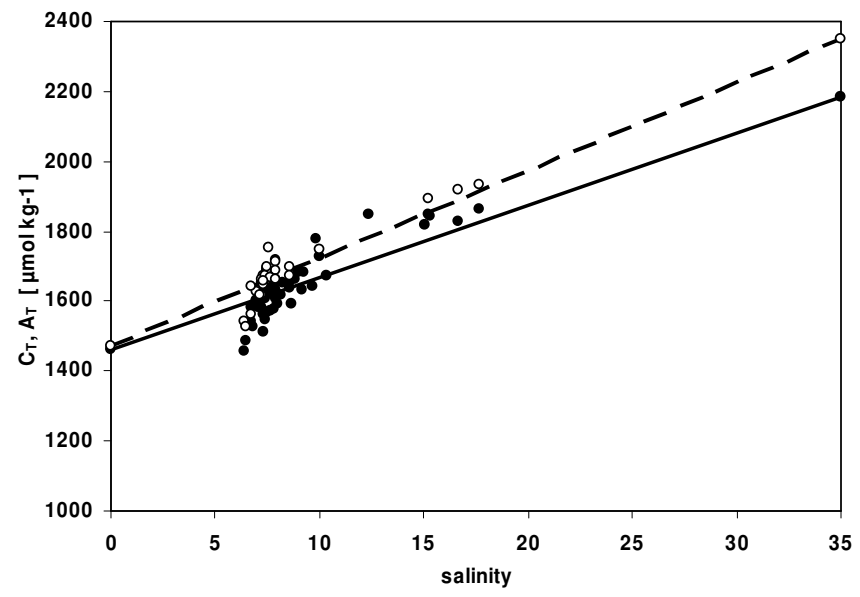

Fig. 21. Regression lines for total $\mathrm{CO}_{2}$ (full circles, solid line) and alkalinity (open circles, dashed line) as a function of salinity. The calculation of the regression lines are based on fixed $C_{\mathrm{T}}$ $\left(2182 \mu \mathrm{mol} \mathrm{kg}{ }^{-1}\right)$ and $A_{\mathrm{T}}(2350 \mu \mathrm{mol} \mathrm{kg}-1)$ at $S_{\mathrm{P}}=35$.

pressure, $p \mathrm{CO}_{2}$. To estimate ${ }^{\circ} C_{\mathrm{T}}$, we first calculated the ocean endmember $\left(S_{\mathrm{P}}=35\right) C_{\mathrm{T}}$ on the basis of the endmember $A_{\mathrm{T}}\left(2350 \mu \mathrm{mol} \mathrm{kg} \mathrm{kg}^{-1}\right)$ and assuming equilibrium with the present day atmospheric $p \mathrm{CO}_{2}$ (about $380 \mu \mathrm{atm}$ ). The calculations were performed for the mean temperature during sampling $\left(5.7^{\circ} \mathrm{C}\right)$ using the $\mathrm{CO}_{2}$ solubility and the $\mathrm{CO}_{2}$ dissociation constants suggested by Weiss (1974) and Millero et al. (2006), respectively. The obtained value $(2182 \mu \mathrm{mol} \mathrm{kg}-1)$ was then fixed for the calculation of a regression line for the $C_{\mathrm{T}}$ /salinity relationship (Fig. 21). Extrapolation of the regression line to $S_{\mathrm{P}}=0$ yielded a mean river water ${ }^{\circ} C_{\mathrm{T}}$ of $1462 \mu \mathrm{mol} \mathrm{kg}{ }^{-1}$. To convert ${ }^{\circ} C_{\mathrm{T}}$ into mass units, the contributions of $\mathrm{CO}_{2}\left(\mathrm{H}_{2} \mathrm{CO}_{3}\right), \mathrm{HCO}_{3}^{-}$and $\mathrm{CO}_{3}^{2-}$ to ${ }^{\circ} C_{\mathrm{T}}$ were calculated from ${ }^{\circ} C_{\mathrm{T}},{ }^{\circ} A_{\mathrm{T}}$ and temperature using again the dissociation constants by Millero et al. (2006). Multiplying the concentrations of the different $C_{\mathrm{T}}$ species with the corresponding molecular weight resulted in a mean river water total $\mathrm{CO}_{2}$ of $89 \mathrm{mg} \mathrm{kg}^{-1}$. The minimum and maximum values were $79 \mu \mathrm{mol} \mathrm{kg}{ }^{-1}$ and $101 \mu \mathrm{mol} \mathrm{kg}{ }^{-1}$, respectively. Hence, the mean total Absolute Salinity anomaly that refers to the selected sampling stations amounted to $118 \mathrm{mg} \mathrm{kg}^{-1}$ (29 $\mathrm{mg} \mathrm{kg}^{-1}$ from $\mathrm{CaCO}_{3}$ and $89 \mathrm{mg} \mathrm{kg}^{-1}$ from $\mathrm{CO}_{2}$ ) and varied between $106 \mathrm{mg} \mathrm{kg}^{-1}$ and $133 \mathrm{mg} \mathrm{kg}^{-1}$. This range is consistent with the estimate available from Fig. 10.

\section{Discussion}

The conditions in the Baltic Sea can serve as a "magnifying glass" for the problems we may encounter in the ocean when more data on composition anomalies will be available that cover the globe more densely and extend over many decades. The effects in the Baltic are measured easier and the relevant time scales are shorter. Nevertheless, the complex processes responsible for composition anomalies and for the spatial and temporal variations of these anomalies are far from being well understood, even in a small estuary such as the Baltic.

In preparation for the analysis of recently collected data we have reconsidered the measurements of Kremling 196669 using the new equation of state (TEOS-10, IOC, 2010). The parameterisation of the salinity anomaly as a function of the Reference Salinity, (5), Fig. 1, and of the chlorinity, (8), Fig. 3, resulted in new equations valid for that observation period, in particular, in an extrapolated Absolute Salinity of $150 \mathrm{mg} \mathrm{kg}^{-1}$ at zero Reference Salinity, and of $173 \mathrm{mg} \mathrm{kg}^{-1}$ at zero chlorinity for the Kremling data. For our recent measurements from 2006 to 2009, these values have changed to $87 \mathrm{mg} \mathrm{kg}^{-1}$ at zero Reference Salinity, Fig. 8, and $130 \mathrm{mg} \mathrm{kg}^{-1}$ at zero chlorinity, Fig. 9. This is a reduction of the anomaly by $42 \%$ and $25 \%$, respectively, over the last 40 years. Of these two, the new chlorinity intercept is derived from only six data points (three chlorinity values) and must be considered as relatively uncertain since values observed at different times or positions may scatter significantly. Our finding of a reduced anomaly is in contrast to the results of Kremling and Wilhelm (1993) who described an increase of the anomaly after 1970 .

The new (Eq. 14) that estimates Absolute Salinity $S_{\mathrm{A}}$ from Reference Salinity $S_{\mathrm{R}}$ of Baltic seawater is based on 436 measured samples, Fig. 8, and is confirmed by independent determinations of density and conductivity, Fig. 9:

$S_{\mathrm{A}}=S_{\mathrm{R}}+87 \mathrm{mgkg}^{-1} \cdot\left(1-\frac{S_{\mathrm{R}}}{S_{\mathrm{SO}}}\right)$

Here, $S_{\mathrm{SO}}=35.16504 \mathrm{~g} \mathrm{~kg}^{-1}$ is the standard-ocean Reference Salinity that corresponds to the Practical Salinity of 35. Reference Salinity, $S_{\mathrm{R}}$, is computed from Practical Salinity, $S_{\mathrm{P}}$, by means of (Eq. 2).

In this paper we have consequently used a regression method that was, to our knowledge, first introduced by Millero and Kremling (1976) to study the Baltic Sea anomalies. In this method, Baltic Sea water is considered as a mixture of Standard Seawater that has standard-ocean salinity, with riverine water which contains unknown amounts of unknown solutes. Properties of diluted Standard Seawater can be computed from the equation of state and compared with Baltic seawater properties of the same salinity, conductivity or chlorinity. In using this method, the Baltic anomalies are assumed to disappear at related standard-ocean conditions such as $S_{\mathrm{R}}=S_{\mathrm{SO}}$, (Eq. 1). This end member datum permits a robust regression with respect to the scattered readings obtained from the Baltic Sea at different positions, times and salinities, and a correspondingly rigorous extrapolation to the opposite end member, the average riverine water. Since a Reference Composition model was defined recently as a part of the new international seawater standard (Millero et al., 2008; IAPWS, 2008; IOC 2009, 2010), the oceanic component can be computed on this basis, resulting in well-defined anomalies that can be compared between different studies. 
This is a significant advantage over the earlier situation when every author used his particular preferred seawater composition model, thus giving incompatible quantitative results for the anomalies between different studies. Such a lack of comparability is especially inconvenient and possibly misleading for trend analyses of e.g. the density anomaly on decadal or century time scales. We have applied this regression method based on the Reference Composition to the anomalies of density, as described in the previous paragraph, to historical and to our recent data, as well as to the conductivity, Fig. 4, and the sulphate anomaly, Fig. 20.

Except for the fact that the composition anomaly of the Baltic Sea is caused by the freshwater composition and is assumed to be proportional to the particular freshwater fraction, the method applied here does not rely on any particular property of the freshwater part, neither its origin nor its composition, its variability or its age. The majority of the freshwater in the Baltic is from river discharge, so we used "river water" synonymously with freshwater. The residence time of 10-30 years implies that the largest fraction of freshwater found in a given sample is not "fresh", i.e. immediately discharged from a river, rather, it is aged in different water bodies over years or decades. From the data scatter of the correlations it is evident that the properties of the freshwater fraction are not independent of its age, its history or its origin. In this sense, the freshwater aging process also includes sinks, sources or interactions with the sediments and the atmosphere. We did not intend to resolve the complex processes that are responsible in detail for the scatter observed, except for the simple conservative mixing with standard ocean water.

The effect of composition anomalies on the conductivity, i.e., the Practical Salinity, is considered in quantitative detail in recent papers of Pawlowicz $(2008$, 2009). The effect of such anomalies on thermodynamic properties was studied by Millero (1974) by using Young's rule. A new approach to this problem is possible by Pitzer models (Feistel and Marion, 2007). The measurements analysed in this paper are intended to support future model studies, first, of the effect of $\mathrm{CaCO}_{3}$ excess on thermodynamic properties of seawater derived from Pitzer equations (Feistel and Marion, 2007), and second, of the anomalous effects on the electrical conductivity of mixed aqueous electrolytes (Pawlowicz, 2008, 2009). In order to support independent investigations and future comparisons, observational data of this study are available from the digital Supplement (http://www.ocean-sci. net/6/3/2010/os-6-3-2010-supplement.zip) of this paper.

Since 1902, oceanographers routinely measure the salinity of seawater relative to certified samples of Standard Seawater. These salinity measurements are not traceable to SI standards (Seitz, 2008) which implies reduced comparability and increasing uncertainty of the results on climatological timescales. For selected Baltic Sea samples, SItraceable state-of-the-art measurements of electrolytic conductivity and density were carried out at the PTB Braun- schweig. The results reported in Sect. 4.2 and 4.3 indicate that the density of seawater can be measured with significantly smaller uncertainty than the conductivity. These findings support the intended proposal of the SCOR/IAPSO WG127 to calibrate instruments for salinity measurements in the future with respect to density rather than or in addition to conductivity. Further studies are required to develop this technology in more detail.

Acknowledgements. The authors like to thank the crew of $\mathrm{r} / \mathrm{v}$ Aranda for providing seawater samples from its cruise in 2009 , and Javid Safarov and the chiefmate, Mr. Langner, for providing samples from the ferry "Finlandia". They are grateful to K. Kremling and F. J. Millero for information regarding their earlier work, and the anonymous referees for helpful hints. This paper contributes to the tasks of the SCOR/IAPSO Working Group 127 on Thermodynamics and Equation of State of Seawater.

Edited by: R. Tailleux

\section{References}

Anderko, A. and Lencka, M. M.: Computation of electrical conductivity of multicomponent aqueous systems in wide concentration and temperature ranges, Ind. Eng. Chem. Res., 36, 1932-1943, 1997.

Brinkmann, F., Dam, N. E., Deák, E., Durbiano, F., Ferrara, E., Fükö, J., Jensen, H. D., Máriássy, M., Shreiner, R. H., Spitzer, P., Sudmeier, U., Surdu, M., and Vyskocil, L.: Primary methods for the measurement of electrolytic conductivity, Accred. Qual. Assur., 8, 346-353, 2003.

Comeau, S., Gorsky, G., Jeffree, R., Teyssié, J.-L., and Gattuso, J.P.: Impact of ocean acidification on a key Arctic pelagic mollusc (Limacina helicina), Biogeosciences, 6, 1877-1882, 2009, http://www.biogeosciences.net/6/1877/2009/.

Culkin, F. and Cox, R. A.: Sodium, potassium, magnesium, calcium and strontium in seawater, Deep-Sea Res., 13, 789-804, 1966.

Culkin, F. and Smith, N.: Determination of the concentration of potassium chloride solution having the same electrical conductivity, at $15^{\circ} \mathrm{C}$ and infinite frequency, as standard seawater of salinity $35.0000 \%$ o(Chlorinity $19.37394 \%$ o), IEEE J. Oceanic Eng., 5, 22-23, 1980.

Dickson, A. G., Sabine, C. L. and Christian, J. R.: Guide to best practice for ocean $\mathrm{CO}_{2}$ measurements, PICES Special Publication 3, 191 pp., 2007.

Dyrssen, D.: The Baltic-Kattegat-Skagerrak estuarine system, Estuaries, 16, 446-452, 1993.

Feistel, R.: New shoreline map-drawing data available, Eos, 80, 249, 1999, available at http://www.io-warnemuende.de/ rainer-feistel.html, 1999.

Feistel, R.: A Gibbs Function for Seawater Thermodynamics for 6 to $80^{\circ} \mathrm{C}$ and Salinity up to $120 \mathrm{~g} / \mathrm{kg}$, Deep-Sea Res. Pt. I, 55, 1639-1671, 2008.

Feistel, R., Feistel, S., Nausch, G., Szaron, J., Lysiak-Pastuszak, E., and Ærtebjerg, G.: BALTIC: Monthly time series 1900-2005, edited by: Feistel, R., Nausch, G., and Wasmund, N., State and Evolution of the Baltic Sea, 1952-2005, A Detailed 50-Year Survey of Meteorology and Climate, Physics, Chemistry, Biology, 
and Marine Environment, John Wiley \& Sons, Inc., Hoboken, 311-336, 2008.

Feistel, R. and Marion, G. M.: A Gibbs-Pitzer Function for HighSalinity Seawater Thermodynamics, Progr. Oceanogr., 74, 515539, 2007.

Feistel, R. and Weinreben, S.: Is Practical Salinity conservative in the Baltic Sea? available at: http://www.iopan.gda.pl/ oceanologia/50_1.html\#A6, Oceanologia, 50, 73-82, 2008.

Feistel, R., Wright, D. G., Jackett, D. R., Miyagawa, K., Reissmann, J. H., Wagner, W., Overhoff, U., Guder, C., Feistel, A., and Marion, G. M.: Numerical Implementation and Oceanographic Application of the Thermodynamic Potentials of Water, Vapour, Ice, Seawater and Air. Part I: Background and Equations, Ocean Science, submitted, 2010.

Fonselius, S. H.: Hydrography of the Baltic deep basins II, Fishery Board of Sweden, Ser. Hydrogr., 20, 1-31, 1967.

Forch, C., Knudsen, M. and Sørensen, S. P. L.: Berichte über die Konstantenbestimmungen zur Aufstellung der hydrographischen Tabellen, gesammelt von Martin Knudsen, Det Kongelige Danske Videnskabernes Selskabs Skrifter, 6, 1-152, 1902.

GUM: Evaluation of measurement data - Guide to the expression of uncertainty in measurement (GUM), JCGM 100:2008, available at www.bipm.org/en/publications/guides/gum, 2008.

Hjalmarsson, S., Wesslander, K., Anderson, L. G., Omstedt, A., Perttila, M., and Mintrop, L.: Distribution, long-term development and mass balance calculation of total alkalinity in the Baltic Sea, Cont. Shelf Res., 28, 593-601, 2008.

IAPWS: Release on the IAPWS Formulation 2008 for the Thermodynamic Properties of Seawater, The International Association for the Properties of Water and Steam, Berlin, Germany, September 2008, available at: http://www.iapws.org, 2008.

IOC: Resolution XXV-7, INTERNATIONAL THERMODYNAMIC EQUATION OF SEAWATER (TEOS-10), INTERGOVERNMENTAL OCEANOGRAPHIC COMMISSION (of UNESCO), Twenty-fifth Session of the Assembly, Paris, 1625 June 2009.

IOC, 2010: The international thermodynamic equation of seawater - Calculation and use of thermodynamic properties, Intergovernmental Oceanographic Commission, Manuals and Guides No. xx., UNESCO (English), 171 pp., available at http://www. TEOS-10.org, 2010.

Jones, N.: Metrology: The new and improved kelvin, Nature, 459, 902-904, 2009.

Knudsen, M.: Hydrographische Tabellen, G. E. C. Gad, Copenhagen, 1901.

Kremling, K.: Untersuchungen zur chemischen Zusammensetzung des Meerwassers aus der Ostsee I, Kiel. Meeresforsch., 25, 81104, 1969.

Kremling, K.: Untersuchungen zur chemischen Zusammensetzung des Meerwassers aus der Ostsee II, Kiel. Meeresforsch., 26, 120, 1970.

Kremling, K.: New method for measuring density of seawater, Nature, 229, 109-110, 1971.

Kremling, K.: Untersuchungen zur chemischen Zusammensetzung des Meerwassers aus der Ostsee III, Kiel. Meeresforsch., 28, 99118, 1972.

Kremling, K. and Wilhelm, G.: Recent increase of the calcium concentrations in Baltic Sea waters, Mar. Poll. Bull., 34, 763-767, 1997.
Kwiecinski, B.: The relation between the chlorinity and the conductivity in Baltic water, Deep-Sea Res., 12, 113-120, 1965.

Marion, G. M., Millero, F. J., and Feistel, R.: Precipitation of solid phase calcium carbonates and their effect on application of seawater $S_{\mathrm{A}}-T-P$ models, Ocean Sci., 5, 285-291, 2009, http://www.ocean-sci.net/5/285/2009/.

Matthäus, W., Nehring, D., Feistel, R., Nausch, G., Mohrholz, V., and Lass, H. U.: The inflow of highly saline water into the Baltic Sea, edited by: Feistel, R., Nausch, G., and Wasmund, N., State and Evolution of the Baltic Sea, 1952-2005, A Detailed 50-Year Survey of Meteorology and Climate, Physics, Chemistry, Biology, and Marine Environment, John Wiley \& Sons, Inc., Hoboken, 265-309, 2008.

McDougall, T. J., Jackett, D. R., and Millero, F. J.: An algorithm for estimating Absolute Salinity in the global ocean, Ocean Sci. Discuss., 6, 215-242, 2009,

http://www.ocean-sci-discuss.net/6/215/2009/.

Meier, H. E. M.: Modeling the pathways and ages of inflowing saltand freshwater in the Baltic Sea estuarine, Coast. Shelf Sci., 74, 610-627, 2007.

Meier, H. E. M., Feistel, R., Piechura, J., Arneborg, L., Burchard, H., Fiekas, V., Golenko, N., Kuzmina, N., Mohrholz, V., Nohr, C., Paka, V. T., Sellschopp, J., Stips, A., and Zhurbas, V.: Ventilation of the Baltic Sea deep water: A brief review of present knowledge from observations and models, Oceanologia, 48(S), 133-164, available at http://www.iopan.gda.pl/oceanologia/48_ S.html\#A8, 2006.

Millero, F. J.: Seawater as a multicomponent electrolyte solution, The Sea, edited by: Goldberg, E. D., Wiley-Interscience, 5, 380, 1974.

Millero, F. J.: The marine inorganic carbon cycle, Chem. Rev., 107, 308-341, 2007.

Millero, F. J., Feistel, R., Wright, D. G. and McDougall, T. J.: The composition of Standard Seawater and the definition of the Reference-Composition Salinity Scale, Deep-Sea Res. Pt. I, 55, 50-72, 2008.

Millero, F. J., Forsht, D., Means, D., Giekes, J., and Kenyon, K.: The density of North Pacific Ocean waters. J. Geophys. Res. 83, 2359-2364, 1978.

Millero, F. J., Graham, T. B., Huang, F., Bustos-Serrano, H., and Pierrot, D.: Dissociation constants of carbonic acid in seawater as a function of salinity and temperature, Mar. Chem., 100, 8094, 2006.

Millero, F. J., Huang, F., Williams, N., Waters, J., and Woosley, R.: The effect of composition on the density of South Pacific Ocean waters, Mar. Chem. 114, 56-62, 2009.

Millero, F. J. and Kremling, K.: The densities of Baltic Waters, Deep-Sea Res., 23, 1129-1138, 1976.

Millero, F. J, Waters, J., Woosley, R., Fen Huang, F., and Mareva Chanson, M.: The effect of composition on the density of Indian Ocean waters, Deep-Sea Res. Pt. I, 55, 460-470, 2008.

Morris, A. W. and Riley, J. P.: The bromide/chlorinity and sulphate/chlorinity ratio in seawater, Deep-Sea Res., 13, 699-705, 1966.

Nausch, G., Nehring, D., and Nagel, K.: Nutrient concentrations, trends and their relation to eutrophication, edited by: Feistel, R., Nausch, G., and Wasmund, N., State and Evolution of the Baltic Sea, 1952-2005, A Detailed 50-Year Survey of Meteorology and Climate, Physics, Chemistry, Biology, and Marine Environment, 
John Wiley \& Sons, Inc., Hoboken, 265-309, 2008.

Nehring, D.: Das Nährstoffregime der Ostsee - seine Veränderungen im Zeitraum 1969 bis 1978 - Ursachen und Auswirkungen, Dissertation B, Warnemünde 1980.

Nehring, D. and Rohde, K.-H.: Weitere Untersuchungen über anomale Ionenverhältnisse in der Ostsee, Beitr. Meeresk., 20, 10-33, 1967.

Nessim, R. B. and Schlungbaum, G.: Untersuchungen zur Salzgehaltsanomalie, Wiss. Z. Wilhelm-Pieck-Univ. Rostock, 29, No. 3/4, 1980.

Ohlson, M. and Anderson, L.: Recent investigation of total carbonate in the Baltic Sea: changes from the past as a result of acid rain? Mar. Chem., 30, 259-267, 1990.

Omstedt, A., Gustafsson, E., and Wesslander, K.: Modelling the uptake and release of carbon dioxide in the Baltic Sea surface water, Cont. Shelf Res., 29, 870-885, 2009.

Pawlowicz, R.: Calculating the conductivity of natural waters, Limnol. Oceanogr.-Methods, 6, 489-501, 2008.

Pawlowicz, R.: A model for predicting changes in the electrical conductivity, practical salinity, and absolute salinity of seawater due to variations in relative chemical composition, Ocean Sci. Discuss., 6, 2861-2909, 2009, http://www.ocean-sci-discuss.net/6/2861/2009/.

Perkin, R. G. and Lewis, E. L.: The Practical Salinity Scale 1978, Fitting the data, IEEE J. Ocean. Eng., OE-5, 9-16, 1980.

Reissmann, J. H., Burchard, H., Feistel, R., Hagen, E., Lass, H. U., Mohrholz, V., Nausch, G., Umlauf, L., and Wieczorek, G.: State-of-the-art review on vertical mixing in the Baltic Sea and consequences for eutrophication, Progr. Oceanogr., 82, 47-80, 2009.

Rohde, K.-H.: Untersuchungen über die Calcium- und Magnesiumanomalie in der Ostsee, Beitr. Meeresk., 19, 18-31, 1966.

SeaBird: 1978 Practical Salinity Scale, Application Note No. 14, revised January 1989, last modified 6 July 2009, Sea-Bird Electronics, available at: http://www.seabird.com/application_notes/ AN14.htm, 1989.

Seitz, S., Spitzer, P., and Brown, R. J. C.: Consistency of practical salinity measurements traceable to primary conductivity standards: Euromet project 918, Accred. Qual. Assur., 13, 601-605, 2008
Stalcup, M. C.: Salinity Measurements, WOCE Operations Manual, Part 3.1.3, WHP Operations and Methods, 1991.

Stigebrandt, A. and Wulff, F.: A time-dependent budget model for nutrients in the Baltic Sea, Glob. Biochem. Cy., 3, 63-78, 1989.

Thomas, H. and Schneider, B.: The seasonal cycle of carbon dioxide in Baltic Sea surface waters, J. Mar. Sys., 22, 53-67, 1999.

Trzosinska, A.: Metoda Knudsena-Sörensen w zastosowaniu do bedania zasolenia wody potudniowego Baltiku, Przegl. Geofiz., 314, 84-88, 1967.

Veron, J. E. N., Hoegh-Guldberg, O., Lenton, T. M., Lough, J. M., Obura, D. O., Pearce-Kelly, P., Sheppard, C. R. C., Spalding, M., Stafford-Smith, M. G., and Rogers, A. D.: The coral reef crisis: The critical importance of $<350 \mathrm{ppm} \mathrm{CO}_{2}$, Mar. Poll. Bull. 58, 1428-1436, 2009.

VIM: International vocabulary of metrology - Basic and general concepts and associated terms (VIM), JCGM 200:2008, available at www.bipm.org/en/publications/guides/vim, 2008.

Voipio, A.: On the magnesium content in the Baltic, Suomen Kemistilehti, B30, 84-88, 1957.

Weiss, R. F.: Carbon dioxide in water and seawater: the solubility of a non-ideal gas, Mar. Chem., 2, 203-215, 1974.

Wolf, H.: Determination of water density: limitations at the uncertainty level of $1 \times 10^{-6}$, Accred. Qual. Assur., 13, 587-591, 2008.

Wright, D. G., Feistel, R., Jackett, D. R., Miyagawa, K., Reissmann, J. H., Wagner, W., Overhoff, U., Guder, C., Feistel, A., and Marion, G. M.: Numerical Implementation and Oceanographic Application of the Thermodynamic Potentials of Water, Vapour, Ice, Seawater and Air. Part II: The Library Routines, Ocean Science, to be submitted, 2010.

Zarins, E. and Ozolins, J.: Untersuchungen über die Zusammensetzung des Meerwassers im Rigaischen Meerbusen und an der lettlandischen Küste des baltischen Meeres, J. Conseil, 10, 275-301, 1935. 